\title{
Aspectos da anatomia ecológica de folhas de Hevea brasiliensis Müell. Arg. (1)
}

\author{
Moacyr Eurípedes Medri (") \\ Eduardo Lleras ("*)
}

\section{Resumo}

A anatomia e morfologia comparada de folhas de Hevea brasiliensis Müell. Arg. em diferentes microclimas e habitats foram estudadas. Folhas em diferentes estratos foram comparadas e comparações também foram feitas entre folhas de estratos equivalentes entre plantas crescendo na várzea e terra firme. Os resultados mostraram um progressivo xeromorfismo das folhas sob condiçōes mais iluminadas, e maior escleromorfismo em folhas, de estrato comparável, em terra firme do que em várzea. Ambos, xeromorfismo e escleromorfismo estão de acordo com a lei de Zalenski e com a interpretação de Lleras. Os resultados aqui apresentados em Hevea brasiliensis sugerem que esta espécie é mais plástica fenotipicamente que outras espécies pesquisadas anteriormente pelos mesmos autores. Sugere-se então que pode ser feita uma seleção de material que apresenta características de maior tolerância à seca tanto em populaçőes nativas quanto clonais utilizando os critérios desenvolvidos neste trabalho que permitem determinar faixas de variação fenotípica.

\section{INTRODUÇÃo}

Um dos maiores problemas para a monocultura de Hevea brasiliensis nos Neotrópicos consiste em que os clones mais produtivos de latex são ao mesmo tempo muito susceptíveis à presença do fungo Microcyclus ulei atacando as folhas novas, eventualmente causando a murcha das mesmas. Em condições de seringal nativo onde só existem 5-7 árvores por hectare e estas não são selecionadas quanto à produtividade, as árvores estão relativamente isoladas umas das outras e conseqüentemente parcialmente protegidas dos esporos de M. ulei. Além disso, estas árvores predominantemente pouco produtivas são relativamente tolerantes a doença. De fato, o aumento em produtividade parece aumentar a susceptibilidade.

Atualmente estão sendo seguidas duas linhas básicas de pesquisa para obtenção de alto rendimento em monocultura. A primeira consiste em tentar obter clones de Hevea brasiliensis, outras espécies do gênero ou híbridos interespecíficos que sejam produtivos e tolerantes à infestação por M. ulei (Cf. Cailloux \& Lleras, 1979).

A segunda consiste em contornar o problema da infestação plantando em áreas onde o fungo não constitui problema. Estas áreas devem apresentar períodos secos bem definidos, sendo que em termos gerais o lançamento de folhas novas coincide com o período seco e sob estas condições o fungo não tem ca. pacidade de infestar. Assim, há grande interesse em obter clones altamente produtivos com boas características de resistência à seca.

A resistência à seca tem sido de grande interesse nas pesquisas fisiológicas, especialmente em plantas de valor econômico. Maximov (1931) citou uma série de trabalhos russos nos quais se tentava apresentar coeficientes anatômicos para determinar a capacidade de resistência à seca. Em termos gerais, considera-se que as características xeromórficas em folhas são boas indicadoras de resistência à seca. Estas características têm sido repetidamente pesquisadas por diversos autores entre os quais podem citar-se Zalenski (1904), Yapp (1912), Brotherthon \& Bartlett (1918), Salisbury (1927), Maximov (1931), Arens (1958a, 1958b) e Lleras (1977 e s/d) que fez uma revisão crítica da evidência até o presente.

(1) - Parte dos resultados corresponde à Tese apresentada pelo primeiro autor como requisitö para obtençăo do grau de Mestre em Ciências Biológicas - INPA FUA.

(*) - Fundação Universidade do Amazonas e Instituto Nacional de Pesquisas da Amazônia, Manaus.

["*] - Instituto Nacional de Pesquisas da Amazônia, Manaus. 
Trabalhos anteriores dos presentes autores em que foram comparados anatomicamente foIhas de clones diplóides com os respectivos clones poliplóides de Hevea (Medri \& Lleras 1979; Lleras s/d), indicaram que as folhas de clones poliplóides apresentam mais caracteristicas xéricas que as folhas de clones diplóides.

Em outros trabalhos da mesma equipe (Leite \& Lleras, 1978; Medri \& Lleras, s/d), foram feitas comparações anatômicas de folhas em diversos estratos da mesma árvore. Leite \& Lleras (1978) trabalharam com Pogonophora schomburgkiana Miers, encontrando aumento gradual de características xéricas nos estratos mais expostos. Resultados similares foram anotados por Medri \& Lleras (s/d), trabalhando com Bertholletia excelsa Humb. \& Bonpl. (Castanha-do-pará). As possíveis causas foram discutidas por Lleras (1977 e s/d).

Visto que as folhas situadas nos estratos superiores estão em condições mais xéricas, com maior luminosidade, maior temperatura e menor umidade relativa (Selleck \& Shuppert, 1957; Lleras, 1977 e s/d) é de esperar-se que se apresentem características xeromórficas mais pronunciadas do que em folhas de estratos inferiores. Segundo Zalenski (1904), algumas destas características são: células epidérmicas menores e menos sinuosas, parede celular mais espessa, maior número de estômatos por unidade de área, elementos condutores mais freqüentes, maior percentagem de tecidos de sustentação, mesófilo mais espesso e melhor definido com maior percentagem de tecido paliçádico do que lacunoso e tecido de sustentação mais abundante.

Tenta-se, neste trabalho, de determinar se estas variações também aparecem em Hevea brasiliensis, limitando também a faixa de variação fenotípica para estes caracteres. O estabelecimento desta faixa da variação é muito importante se o objetivo é selecionar material com maior resistência à seca (características mais xéricas) sendo que permite estabelecer parâmetros anatômicos básicos de seleção.

Também foram feitas comparações entre folhas de dois habitats diferentes (várzea e terra firme), sendo que é comumente considerado que a várzea apresenta quantidades superiores de nutrientes no solo. Stalfelt (1956) postulou que deficiências de nutrientes no solo podem induzir mais xeromorfismo do que a falta de umidade, enquanto que Müller-Stoll (1947), Esau (1960) e Lleras (s/d) preferem o termo escleromorfismo para descrever isto (esta diferença em terminologia é discutida por Lleras (Ibid.). Assim, esperamos encontrar um grau de escleromorfismo maior em foIhas de plantas de terra firme do que em folhas de plantas de várzea

\section{MATERIAL E MÉTODO}

A coleta do material em estudo foi realizada em seringais nativos de dois habitats diferentes: em uma várzea do lago Janauacá (AM.) e terra firme na "Colônia Rosa de Maio", situada nas cercanias do aeroporto Eduardo Gomes, Manaus, Amazonas, Brasil. Nas áreas de estudo não foram encontradas outras espécies de Hevea que pudessem levar a pensar em hibridização interespecífica.

A espécie em estudo, Hevea brasiliensis Müell. Arg., (material testemunho depositado no Herbário do Instituto Nacional de Pesquisas da Amazônia - INPA, sob o número 70.246) é amplamente distribuída na Amazônia, podendo ser encontrada em diversos habitats, tais como terra firme e várzea.

Foram usadas plantas de 3 classes de alturas: plântulas, árvores em torno de $4 \mathrm{~m}$ e árvores de 15 metros de altura, sendo amostrada cada classe de altura em 10 plantas diferentes.

Nas plântulas, foram coletadas folhas adultas a $0,7 \mathrm{~m}$.; nas árvores de 4 metros a amostragem foi realizada a 2 e 4 metros e nas árvores de 15 metros as folhas foram coletadas a $6,8,10$ e 15 metros de altura, tanto para as plantas de várzea como as de terra firme.

As folhas de Hevea brasiliensis são trifolioladas com peciolos relativamente longos e pecíolos reduzidos. O estudo foi realizado em pecíolos e folíolos.

Dissociação de epidermes - Para o estudo das epidermes foram tomados 10 folíolos adultos de dez folhas diferentes de uma mes- 
ma planta e de plantas diferentes para cada altura destes na planta e nos diferentes habitats. Cada folíolo foi medido e determinada sua regiăo média. Dentro desta região e a um $\mathrm{cm}$ da nervura central, retirou-se quadrados de $1 \mathrm{~cm}^{2}$ para comparação do número de estômatos, perímetros das células epidérmicas superiores e inferiores, sinuosidades e espessura das paredes celulares. Não foram comparadas as regiões da base, meio ou ápice de um mesmo folíolo.

As epidermes foram dissociadas com mistura de Jeffrey (ácido crômico $10 \%$ e ácido nítrico $10 \%$ em iguais quantidades) ou por dissociação em água sanitária durante 10 horas. Após dissociação as epidermes foram coloridas em safranina segundo método usual e incluídas em gelatina glicerinada de Kisser. A contagem estomática foi realizada ao microscópio e calculado o número médio de estômatos por $\mathrm{mm}^{2}$ em vinte campos diferentes para cada folíolo. As células epidérmicas foram desenhadas com câmara clara e as medidas de perímetro feitas com "plan measure".

Cortes histológicos - As regiões médias dos pecíolos e folíolos foram fixados em Bouin (ácido acético glacial, formol $40 \%$ e ácido pícrico aquoso saturado na proporção de 1:5:15, respectivamente). Após a fixação e lavagem, o material foi desidratado em série alcoólica e incluído em parafina.

Foram feitos cortes transversais e longitudinais de 12 a $17 \mu \mathrm{m}$ e corados em safranina-verde-luz ou astrablau-fucsina básica (conforme Krieger). Também foram realizados cortes à mão livre do material fresco para comparação .

Todos os desenhos foram realizados com câmara clara e as medidas tomadas com lâmina micrometrada.

Para comparação, calculou-se as percentagens de tecidos de 10 pecíolos e 10 folíolos para todas as alturas destes na planta, em várzea e terra firme. Eles foram calculados segundo método de pesagem de papel vegetal e logo conferidos com planímetro.

As áreas das células paliçádicas (em corte transversal) foram medidas com planímetro e conferidas com o método de pesagem de pa. pel vegetal.

Para visualização de laticíferos, foi usado fixador de Benda (ácido crômico $1 \%$, ácido acético glacial - 2 gotas e ácido ósmico $2 \%$ l e a coloração feita em Sudan IV durante $30 \mathrm{mi}$ nutos (Técnica citada por Bücherl, 1962). Para o estudo da variação do sistema de venação os folíolos foram diafanizados em solução de hidróxido de sódio a $8 \%$, corados em safranina alcoólica e montados com xarope de Apathy.

A contagem de vasos xilemáticos dos pecíolos e nervuras centrais foram realizadas ao microscópio e as medidas de diâmetro feitas com lâmina micrometrada, assim como as de espessura das paredes das células do tecido de sustentação.

O tratamento estatístico foi realizado com o teste Mann-Whitney U (Siegel, 1956). O nivel de significância considerado aqui é de $5 \%$ $(p \leq 0,05)$.

\section{Resultados}

\section{DESCRIÇÃO ANATÔMICA}

Para melhor compreensão deste trabalho, apresenta-se aqui uma breve descrição da morfologia interna do pecíolo, nervura central e lâmina foliolar propriamente dita.

Epiderme uniestratificada, Parênquima cortical formado por 4-5 camadas de células no pecíolo e 2-3 camadas na nervura central. Tecido de sustentação (esclerenquimatoso) formado por células de paredes grossas $(3-6 \mu \mathrm{m})$. formando uma bainha contínua ao redor do floema e laticíferos. Floema contínuo no pecíolo, interrompido na nervura central. Xilema interno ao Floema. Parênquima medular com células de paredes finas e muitos meatos in. tercelulares (Fig. 1 e 2).

A lâmina foliolar apresenta-se revestida pelas epidermes superior e inferior. A cuticula da epiderme superior é lisa, sendo que a inferior mostra saliências oticamente semelhantes a pêlos (já citadas por Bobilioff, 1923). As epidermes superior e inferior não apresentam 


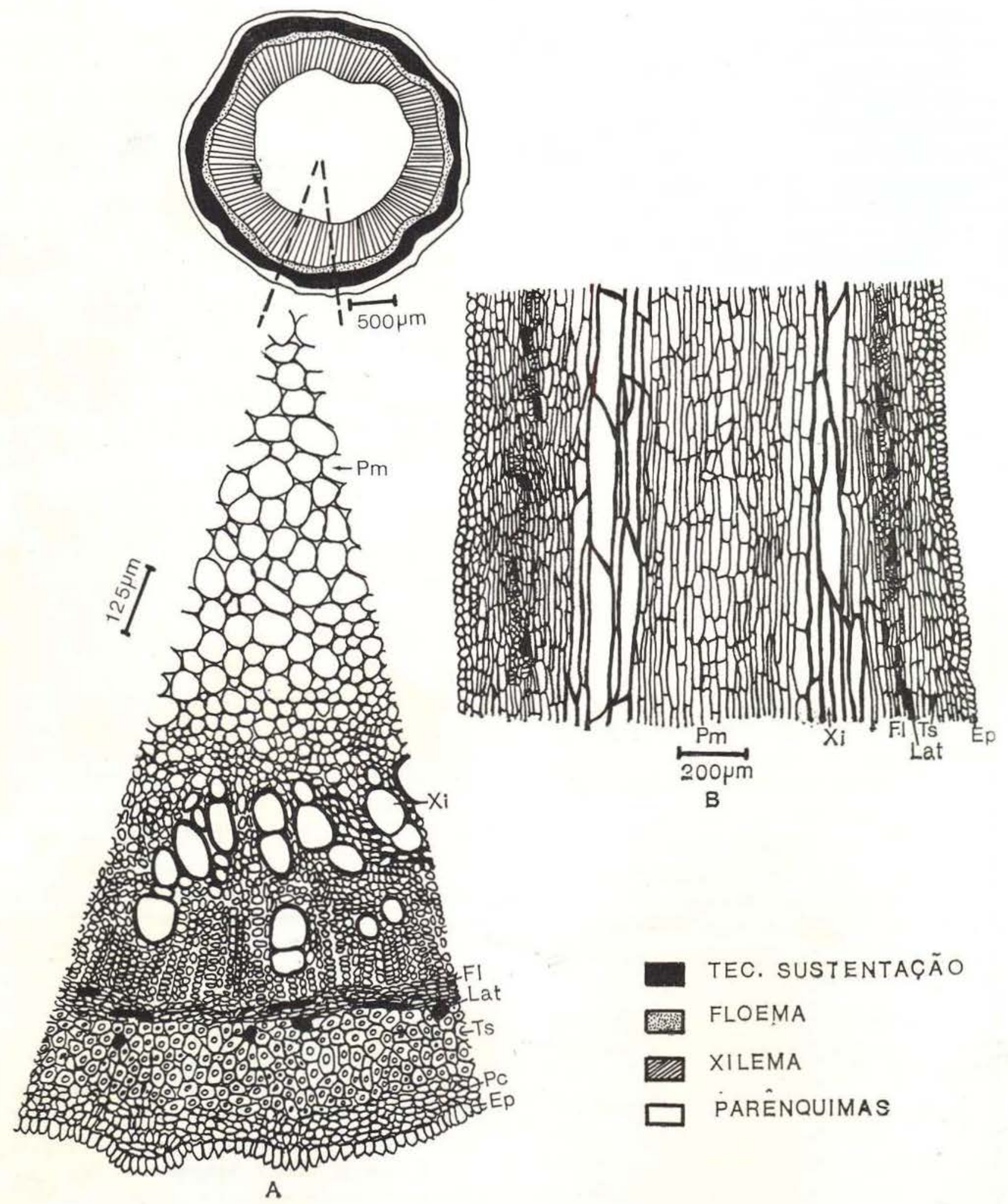

Fig. 1 - Corte transversal (A) e longitudinal (B) de pecíolo. Ep - epiderme: Pc - Parênquima cortical; Ts - Tecido de sustentação; FI e Lat - Floema e Laticíferos; Xi - Xilema; Pm - Parênquima medular. 


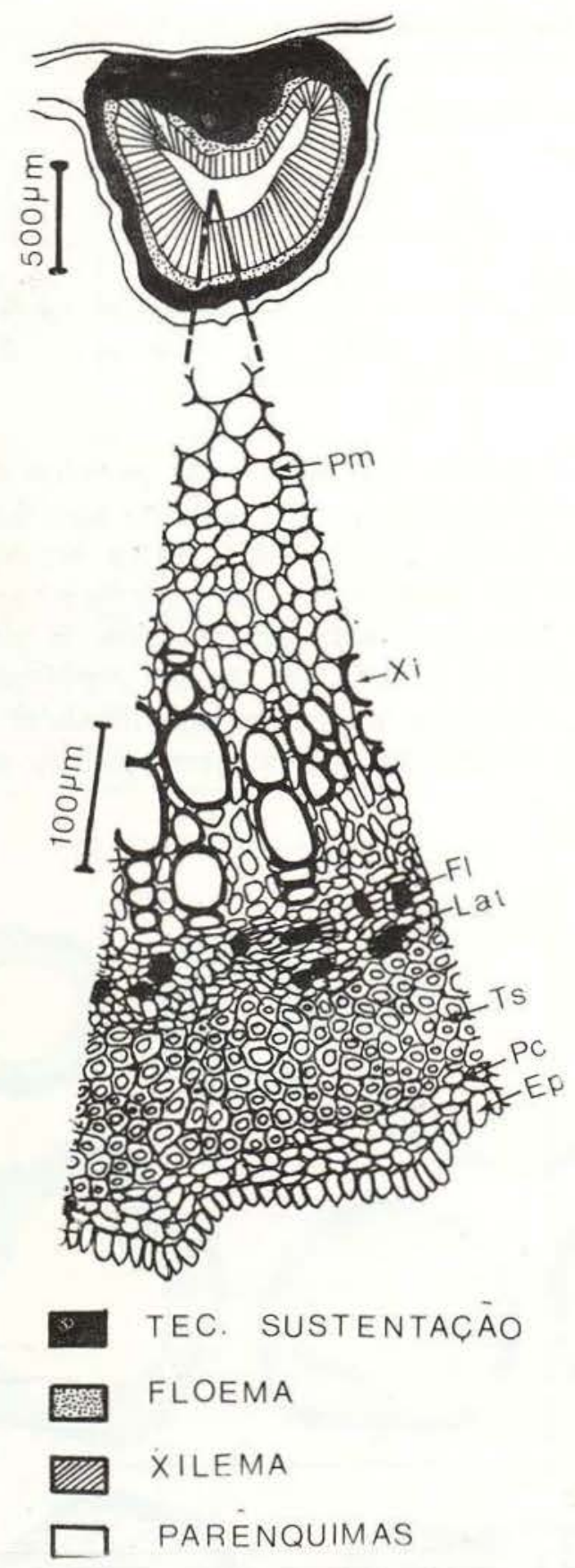

Fig. 2 - Corte transversal da nervura central do folío. lo. Ep - Epiderme Pc - Parênquima cortical; Ts tecido de sustentação; $\mathrm{Fl}$ e Lat - Floema e Laticíferos: $\mathrm{Xi}$ - xilema; $\mathrm{Pm}$ - Parênquima medular.

espaços intercelulares ou cloropiastos (estes. só presentes nos estômatos ou células guardas).

Mesófilo bem definido; parênquima paliçádico adaxial formado por uma camada de células alongadas e justapostas com pouco ou nenhum espaço intercelular; parênquima lacunoso formado por células elípticas distribuídas irregularmente com grandes espaços entre elas. Laticíferos ocorrem na região floemática das nervuras ou entre os parênquimas do mesófilo (Fig. 3).

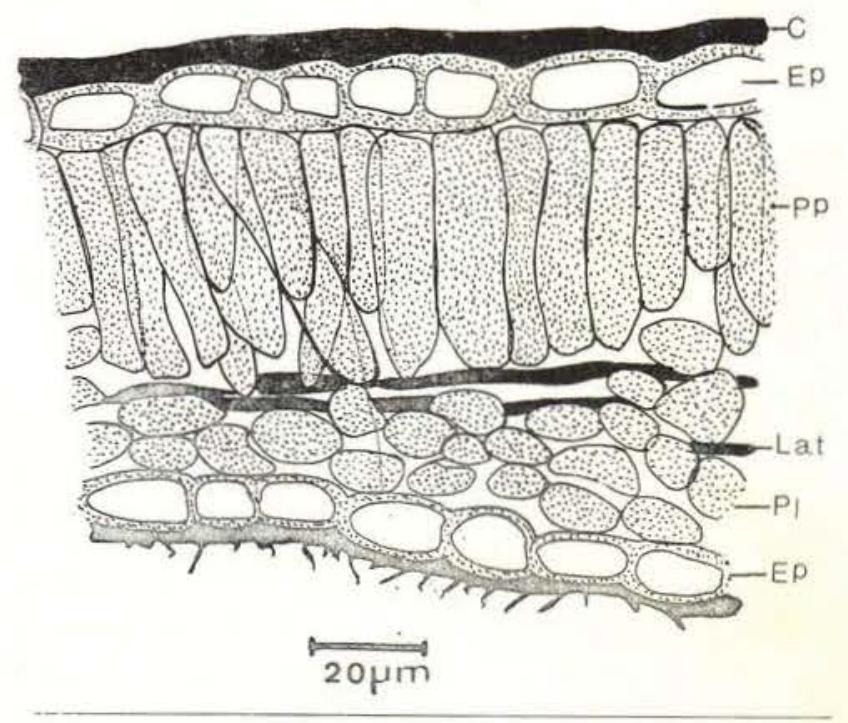

Fig. 3 - Corte transversal de folíolo. Ep - Epidermes; C - Cutícula; Pp - Parênquima paliçádico; PI Parênquima lacunoso; Lat - Laticiferos; L - Lacunas.

PECÍOLOS

O comprimento dos pecíolos das plântulas $(0,7 \mathrm{~m})$ é significativamente menor que nos adultos. Nos adultos, os pecíolos diminuem gradativamente de tamanho com a altura, tanto em várzea quanto em terra firme, sendo significativamente maiores a $2 \mathrm{~m}$ quando comparados com as outras alturas. As plantas de várzea apresentam pecíolos significativamente mais longos nas alturas 2, 4, 6, 8 e 10 metros, que nas mesmas alturas em plantas de terra firme, sendo que a 0,7 e 15 metros nāo existe nenhuma diferença (Tab. 1 e 2; Fig. 4).

O diâmetro dos pecíolos aumenta gradativamente com a altura das folhas, tanto em várzea quanto em terra firme, sendo que, em plantas de terra firme, as diferenças são significativas ao comparar-se todas as alturas, com exceção de $0,7-2,6-8$ e $10-15$, enquanto que, em plantas de várzea, as diferenças significativas só aparecem quando comparadas as alturas $0,7 \mathrm{~m}$ com as demais ou $2 \mathrm{~m}$ com $15 \mathrm{me}$ - 
TABELA 1 - Comprimento médio em $\mathrm{cm}$ de pecíolo nas diferentes alturas nos dois habitats.

\begin{tabular}{|c|c|c|c|c|c|c|c|}
\hline \multirow[b]{2}{*}{ Habitat } & \multicolumn{7}{|c|}{ Comprimento - Pecíolo/Cm $(\bar{x})$} \\
\hline & $0,7 \mathrm{~m}$ & $2 \mathrm{~m}$ & $4 \mathrm{~m}$ & $6 \mathrm{~m}$ & $8 \mathrm{~m}$ & $10 \mathrm{~m}$ & $15 \mathrm{~m}$ \\
\hline Várzea & 8,17 & 23,56 & 17,70 & 16,70 & 15,23 & 15,04 & 15,19 \\
\hline Terra firme & 8,15 & 21,01 & 17,39 & 16,45 & 15,23 & 15,03 & 15,01 \\
\hline
\end{tabular}

TABELA 2 - Comprimento de pecíolo. Resultados dos testes de probabilidades comparando diferentes alturas em um mesmo habitat (várzea ou terra firme) e alturas correspondentes dos dois habitats.

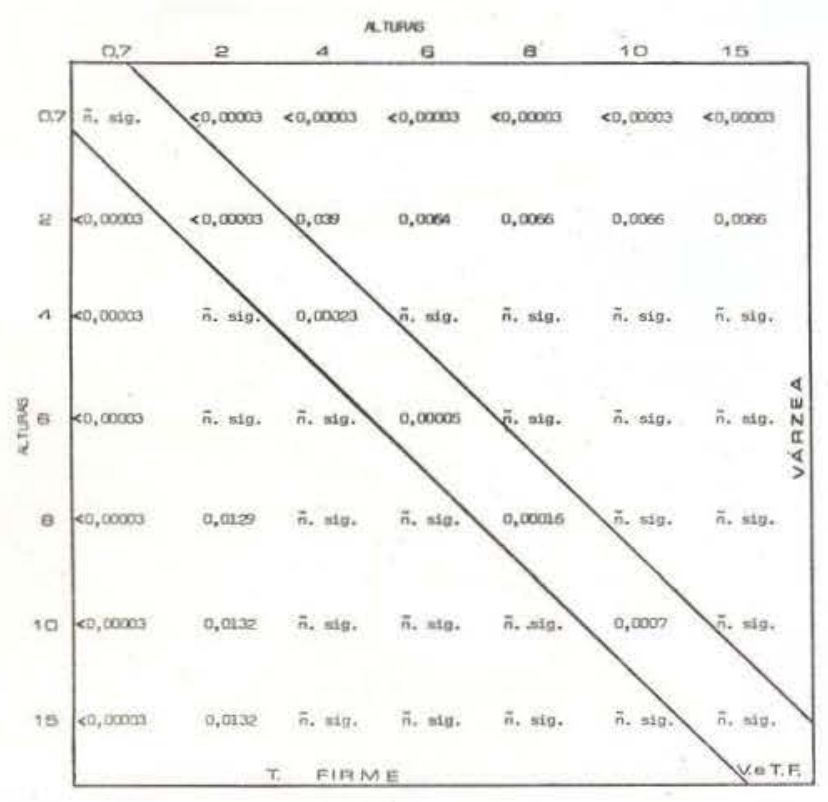

tros. As plantas de várzea apresentam pecíolos significativamente mais espessos nas alturas $2,4,6,8$ e 10 metros, que nas mesmas alturas em plantas de terra firme, sendo que a 0,7 e 15 metros não há diferença significativa. (Tab. 3 e 4 ; Fig. 5 e 6).
O estudo dos tecidos dos pecíolos revela maior percentagem de xilema do que dos demais tecidos, entre $40-50 \%$, tanto em várzea como em terra firme. As variações nas percentagens de xilema, em pecíolos de plantas de várzea e terra firme, não são significativas. A percentagem de parênquima medular está entre $30-20 \%$ da percentagem total do pecío-

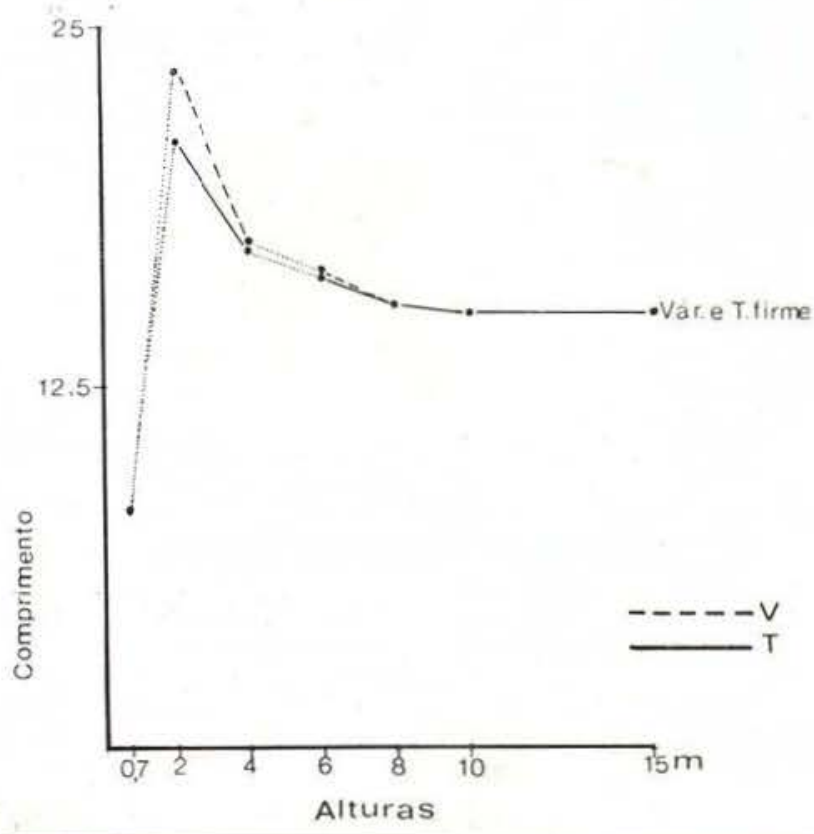

Fig. 4 - Comprimento em $\mathrm{cm}$ de peciolo nas diferentes alturas nos dois habitats.

TABELA 3 - Diâmetro médio $(\mathrm{mm})$ de pecíolos nas diferentes alturas, em várzea e terra firme.

\begin{tabular}{l|c|c|c|c|c|c|c}
\hline & \multicolumn{7}{c}{ Diâmetro - peciolo $(\overline{\mathrm{x}})$} \\
\cline { 2 - 5 } & $0,7 \mathrm{~m}$ & $2 \mathrm{~m}$ & $4 \mathrm{~m}$ & $6 \mathrm{~m}$ & $8 \mathrm{~m}$ & $10 \mathrm{~m}$ & $15 \mathrm{~m}$ \\
\hline Várzea & 1,17 & 1,97 & 2,00 & 2,15 & 2,16 & 2,16 & 2,21 \\
\hline Terra firme & 1,27 & 1,40 & 1,64 & 1,80 & 1,89 & 2,01 & 2,09 \\
\hline
\end{tabular}


TABELA 4 - Diâmetro de pecíolos, Resultados dos tes. tes de probabilidades comparando diferentes alturas em um mesmo habitat (várzea ou terra firme) e alturas cor. respondentes dos dois habitats.

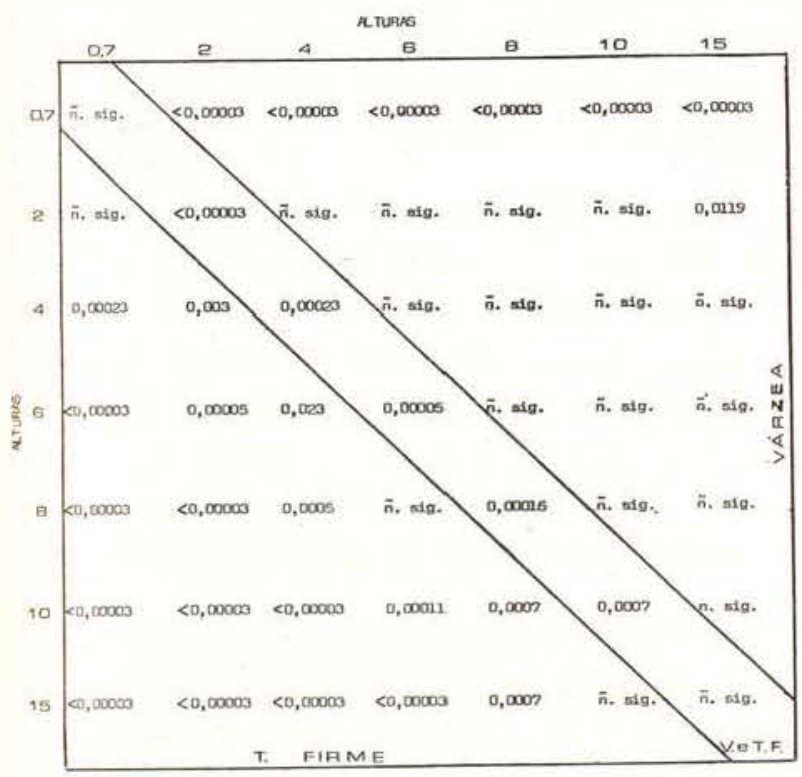

lo, decrescendo com a altura tanto em várzea quanto em terra firme; tecido de sustentação entre 12-16\%; floema incluindo laticíferos $6-14 \%$, todos aumentando com a altura da foIha em várzea e terra firme. As percentagens de parênquima cortical (incluindo epiderme), nas plantas de várzea, está entre $11-15 \%$ e nas plantas de terra firme $7,4-9 \%$, também aumentando com a altura das folhas na planta. (Tab. 5 e 6; Fig. 7).

\section{FOLÍOLOS}

A área dos folíolos das plântulas $(0,7 \mathrm{~m})$ é significativamente menor que nos adultos. Nos adultos, os folíolos diminuem gradativamente com a altura, tanto em várzea quanto em terra firme. A área a $2 \mathrm{~m}$ é significativamente maior que a todas as outras alturas, sendo que, de 4 metros acima, há tendência à es-

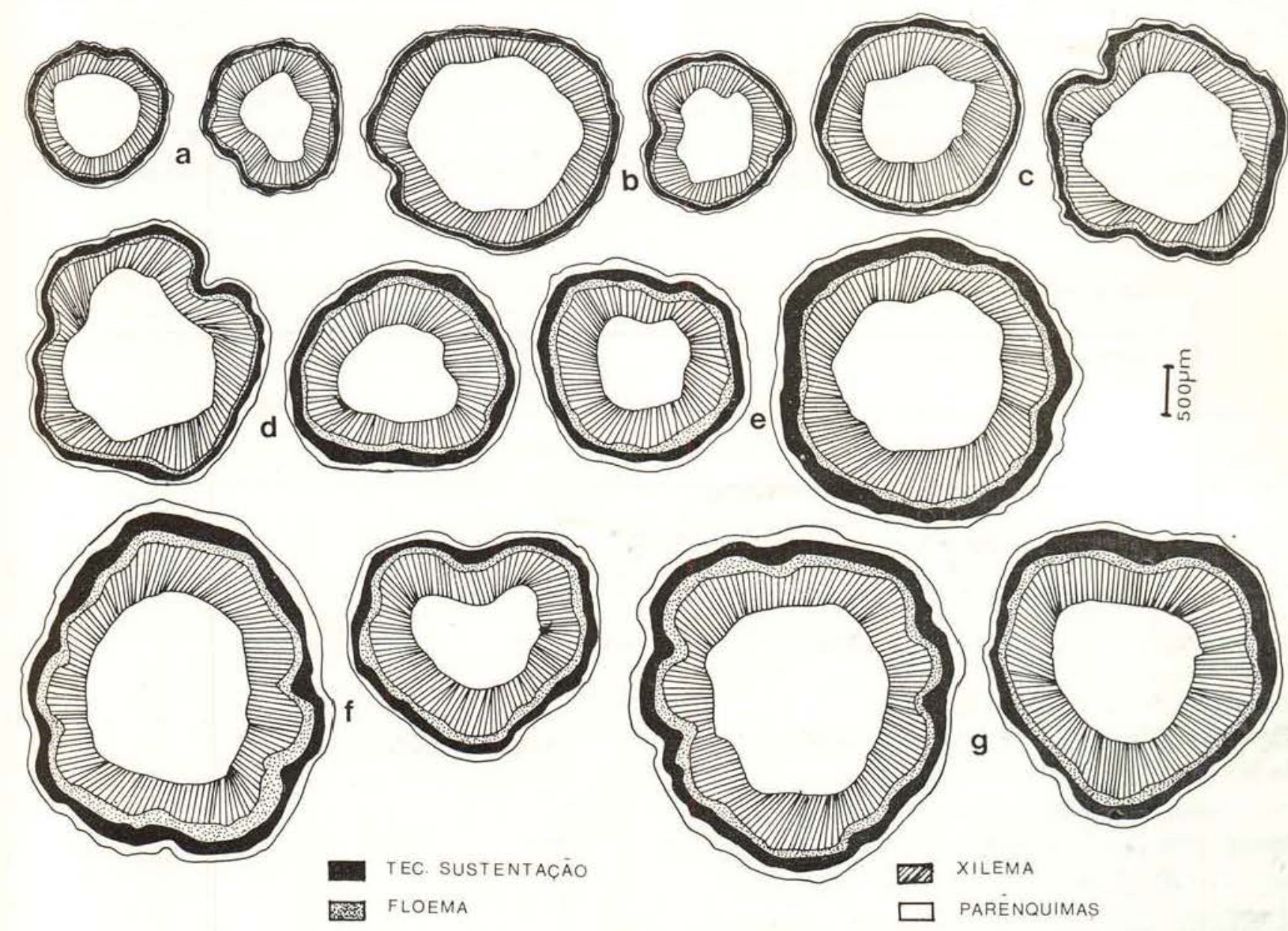

Fig. 5 - Comparação de pecíolos em plantas de várzea (esquerda) e terra firme (direita) nas diferentes alturas. A, 0,7m (plântula); B, $2 \mathrm{~m} ; \mathrm{C}, 4 \mathrm{~m} ; 0,6 \mathrm{~m} ; \mathrm{E}, 8 \mathrm{~m} ; \mathrm{F}, 10 \mathrm{~m} ; \mathrm{G}, 15 \mathrm{~m}$. 


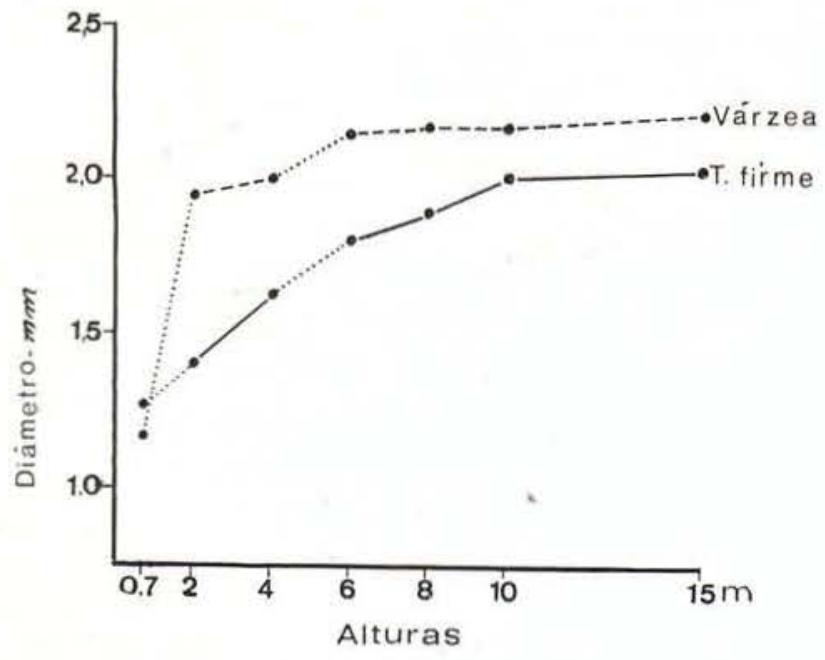

Fig. 6 - Diâmetro médio dos pecíolos nas diferentes alturas da planta, em várzea e terra firme.

tabilização, podendo, ou não, haver diferença estatisticamente significativa. Ainda se os folíolos são maiores em plantas de várzea ao compará-las com folíolos de mesmos extratos em terra firme, as diferenças não são estatisticamente significativas (Tab. 7 e 8 ; Fig. 8).

\section{LÂMINA}

A lâmina apresenta um aumento gradual em espessura com a altura do folíolo na planta, tanto em várzea quanto em terra firme, sendo que acima de 6 metros é mais espessa em plantas de terra firme.

Em corte transversal, as células epidérmicas são tanto mais altas quanto maior a altura do folíolo, sendo a epiderme superior um pouco mais desenvolvida que a inferior. As cutículas superior e inferior apresentam espessamento gradual com a altura, sendo a superior mais espessa que a inferior tanto nas plantas de várzea quanto nas de terra firme (Fig. 9).

O mesófilo dos folíolos das plantas de várzea é constituído adaxialmente por parênquima paliçádico e abaxialmente por parênquima lacunoso. Tanto em plantas de várzea quanto em terra firme, as células paliçádicas apresentamse mais alongadas a maior aliura do folíolo, tendo portanto, maior área estatisticamente significativa em todos os casos. Nos folíolos de plantas de terra firme, as células paliçádi-

TABELA 5 - Percentagens médias dos tecidos do pecíolo nas diferentes alturas em plantas de várzea

\begin{tabular}{|c|c|c|c|c|c|c|c|}
\hline \multirow[b]{2}{*}{ Tecido } & \multicolumn{7}{|c|}{$\%$ de tecidos $(\bar{x})$} \\
\hline & $0,7 \mathrm{~m}$ & $2 \mathrm{~m}$ & $4 \mathrm{~m}$ & $6 \mathrm{~m}$ & $8 \mathrm{~m}$ & $10 \mathrm{~m}$ & $15 \mathrm{~m}$ \\
\hline $\begin{array}{l}\text { Parênquima Corti- } \\
\text { cal e epiderme }\end{array}$ & 11,63 & 6,22 & 6.72 & 7,99 & 9,20 & 13,95 & 15,99 \\
\hline T. sustentação & 12,61 & 10,62 & 11,49 & 13,79 & 15,37 & 16,36 & 16,36 \\
\hline $\begin{array}{l}\text { Floema e laticí- } \\
\text { feros }\end{array}$ & 7,93 & 4,56 & 6,24 & 8,04 & 9,59 & 10,97 & 14,82 \\
\hline Xilema & 41,38 & 44,84 & 42,68 & 41,71 & 42,22 & 35,73 & 35,03 \\
\hline $\begin{array}{l}\text { Parênquima me- } \\
\text { dular }\end{array}$ & 28,54 & 35,61 & 34,28 & 30,09 & 25.90 & 24,36 & 20.21 \\
\hline
\end{tabular}


TABELA 6 - Percentagens médias dos tecidos do pecíolo nas diferentes alturas em plantas de terra firme.

\begin{tabular}{|c|c|c|c|c|c|c|c|}
\hline \multirow[b]{2}{*}{ Tecido } & \multicolumn{7}{|c|}{$\%$ de tecidos $(\bar{x})$} \\
\hline & $0,7 \mathrm{~m}$ & $2 \mathrm{~m}$ & $4 \mathrm{~m}$ & $6 \mathrm{~m}$ & $8 \mathrm{~m}$ & $10 \mathrm{~m}$ & $15 \mathrm{~m}$ \\
\hline $\begin{array}{l}\text { Parênquima Cor- } \\
\text { tical e epiderme }\end{array}$ & 7,45 & 6,58 & 6,98 & 9,90 & 3,52 & 10,23 & 9,00 \\
\hline Tec. sustentação & 13,12 & 11,49 & 11,90 & 17,04 & 15,00 & 14,00 & 16,90 \\
\hline $\begin{array}{l}\text { Floema e laticí- } \\
\text { feros }\end{array}$ & 6,52 & 7,34 & 6,70 & 8,50 & 11,33 & 11,84 & 11,00 \\
\hline Xilema & 40.46 & 48,07 & 49,8 & 41,31 & 40,31 & 43,11 & 43,90 \\
\hline $\begin{array}{l}\text { Perênquima me- } \\
\text { dular }\end{array}$ & 32,41 & 26,51 & 24,58 & 21,77 & 19.97 & 20,80 & 19.50 \\
\hline
\end{tabular}

TABELA 7 - Areas médias $\left(\mathrm{cm}^{2}\right)$ de folíolos nas diferentes alturas em plantas de várzea e terra firme.

\begin{tabular}{|c|c|c|c|c|c|c|c|}
\hline Altura & & & & Folíolos & & & \\
\hline Habitat & $0.7 \mathrm{~m}$ & $2 \mathrm{~m}$ & $4 \mathrm{~m}$ & $6 \mathrm{~m}$ & $8 \mathrm{~m}$ & $10 \mathrm{~m}$ & $15 \mathrm{~m}$ \\
\hline Várzea & 35,34 & 113,86 & 80,97 & 79,91 & 64,04 & 58,53 & 50.54 \\
\hline Terra firme & 31,10 & 93,69 & 68,30 & 62,11 & 61,39 & 56,60 & 47,60 \\
\hline
\end{tabular}

TABELA 8 - Áreas foliolares. Resultados dos testes de probabilidades comparando diferentes alturas em um mesmo habitat (várzea ou terra firme) e alturas correspondentes dos dois habitats.

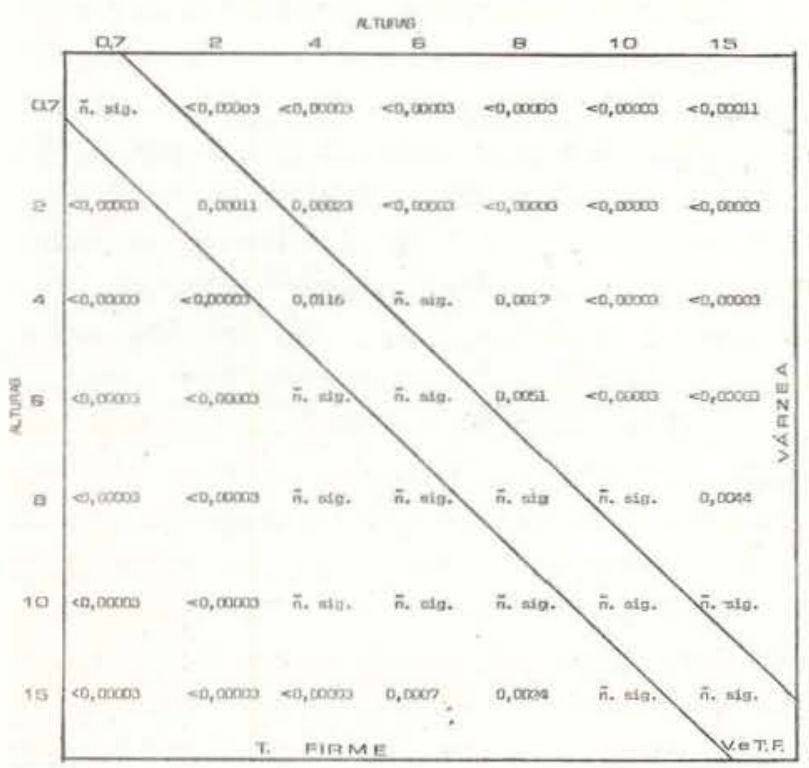

cas apresentam áreas significativamente maiores que em alturas equivalentes de folíolos de plantas em várzea (Tab. 9 e 10; Fig. 9 e 10).

Nas plantas de várzea, a alturas de 0,7 metros (plântulas), 2 e 4 metros, as células paliçádicas são ligeiramente sinuosas, tornandose regulares a alturas de $6,8,10$ e 15 metros. As células parenquimáticas lacunosas são em geral elípticas aumentando de tamanho com a altura.

Em terra firme, a alturas de 0,7 e 2 metros, o mesófilo é constituído adaxialmente por parênquima paliçádico e abaxialmente por parênquima lacunoso. A 4, 6, 8, 10 e 15 metros, as duas faces apresentam parênquima paliçádico, sendo as células paliçádicias adaxiais mais alongadas e sempre com formas bem definidas. Ao contrário das plantas de várzea, o parênquima paliçádico dos folíolos de terra firme é mais uniforme dados a forma 

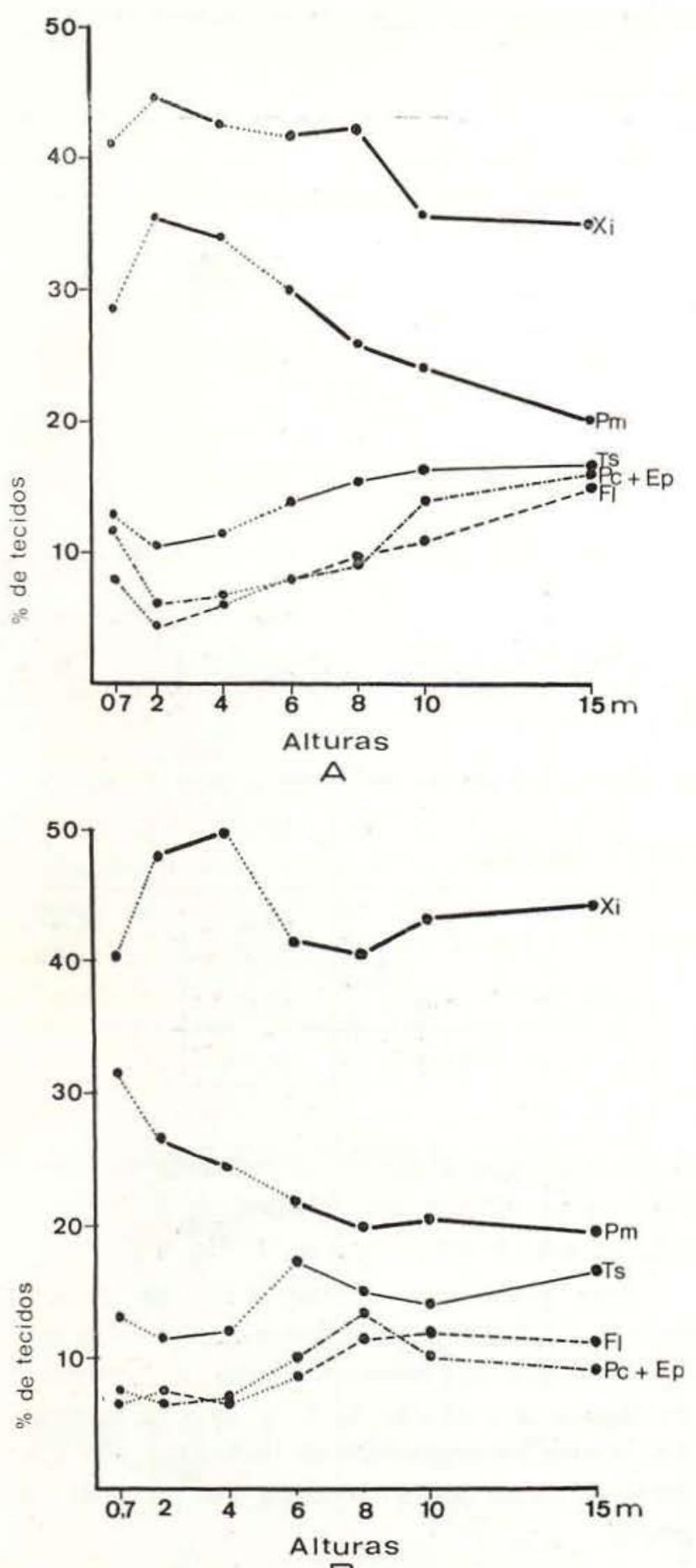

B

Fig. 7 - Percentagens médias dos tecidos do pecíolo de várzea (A) e terra firme (B) nas diferentes alturas em plantas de terra firme. $\mathrm{Xi}-$ xilema; $\mathrm{Pm}$ - parênquima medular; Ts - tecido de sustentação; $\mathrm{Pc}-\mathrm{Pa}$ rênquima cortical; $\mathrm{FI}$ - floema.

definida e comprimento regular das células que o compõe. Nas plantas de terra firme, as células parenquimáticas lacunosas, a alturas

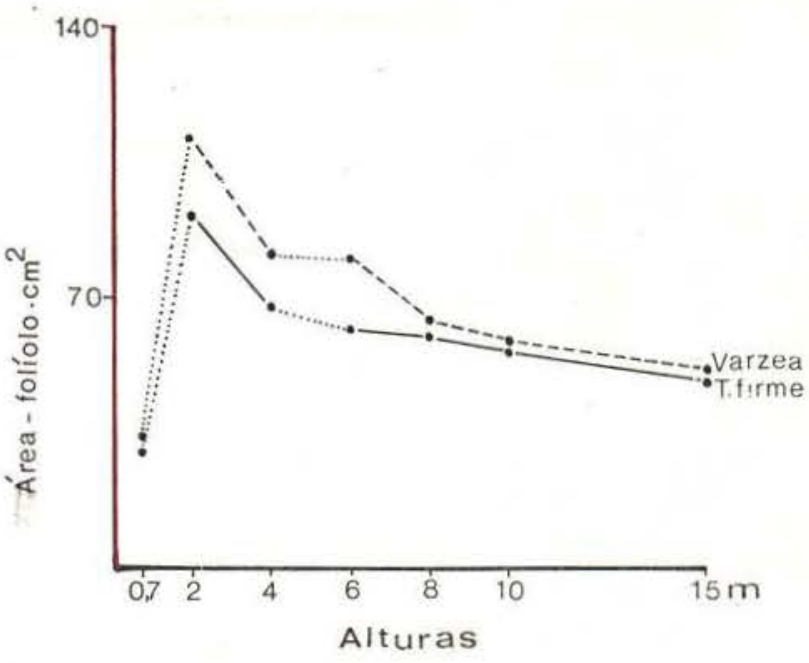

Fig. 8 - Areas médias de folíolos nas diferentes alturas em plantas de várzea e terra firme.

acima de 4 metros, estão situadas, juntamente com os laticíferos, entre os dois parênquimas paliçádicos. As células lacunosas são em geral elípticas não variando em tamanho com a altura dos folíolos (Fig. 9).

A percentagem de parênquima paliçádico aumenta sensivelmente com a altura do folíolo na planta, tanto em várzea quanto em terra firme, alcançando na última maior percentagem. A percentagem de lacunas decresce com a elevação dos folíolos na planta em várzea e terra firme (Tab. 11 e 12; Fig. 11, 12 e 13).

\section{EPIDERMES}

Em vista superficial, as paredes das células epidérmicas superiores dos folíolos de plantas de várzea e terra firme diminuem em sinuosidades e se espessam com a altura. Os folíolos situados em estratos mais baixos, tais como a $0,7,2$ e 4 metros, apresentam epidermes com células sinuosas irregulares e paredes finas. Os folíolos situados em posições superiores tais como a $6,8,10$ e 15 metros, não apresentam células epidérmicas sinuosas e suas paredes são mais espessas. A cutícula superior aumenta gradualmente de espessura com a altura do folíolo. O perímetro superficial das células epi dérmicas, tanto em várzea quanto em terra firme, decresce significativamente com a maior altura, sendo que em alturas correspondentes, 
TABELA 9 - Area média das células paliçádicas (em corte transversal) nas diferentes alturas de plantas de várzea e terra firme.

\begin{tabular}{|c|c|c|c|c|c|c|c|}
\hline \multirow[b]{2}{*}{ Habitat } & \multicolumn{7}{|c|}{ Área $-\overline{\times} \mu^{m^{2}}$} \\
\hline & $0.7 \mathrm{~m}$ & $2 \mathrm{~m}$ & $4 \mathrm{~m}$ & $6 \mathrm{~m}$ & $8 \mathrm{~m}$ & $10 \mathrm{~m}$ & $15 \mathrm{~m}$ \\
\hline Várzea & 86,35 & 100,79 & 144,02 & 190,88 & 252,52 & 297,46 & 355,145 \\
\hline Terra firme & 77,48 & 145,20 & 248,99 & 280,24 & 335,90 & 373,53 & 498,92 \\
\hline
\end{tabular}
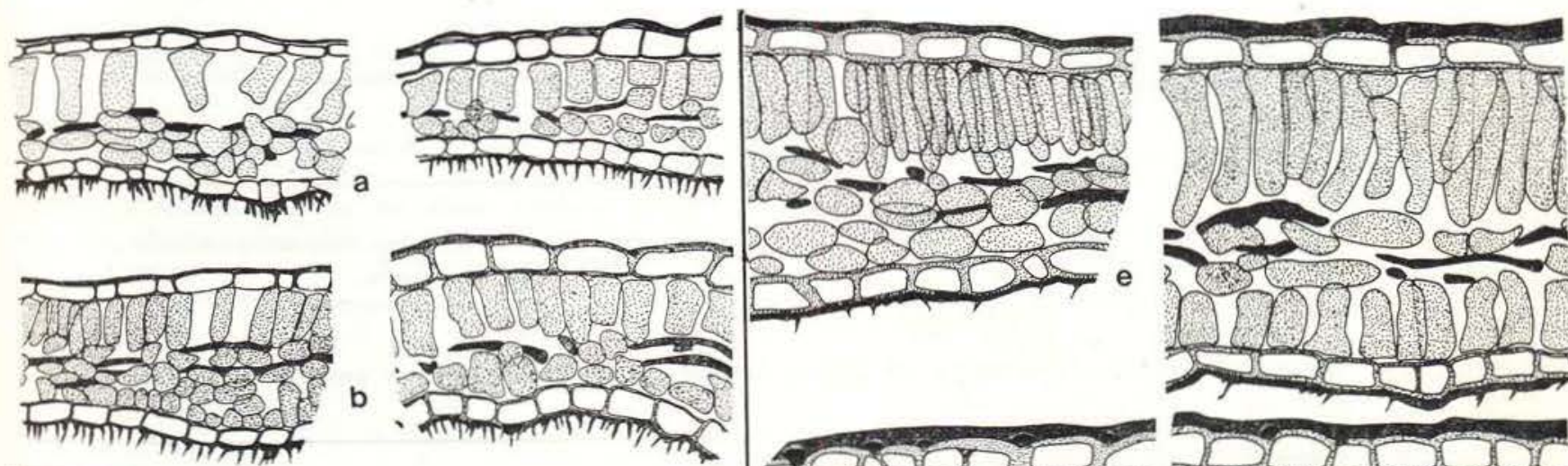

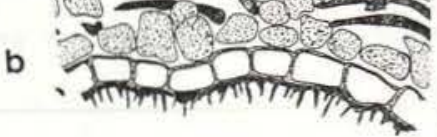
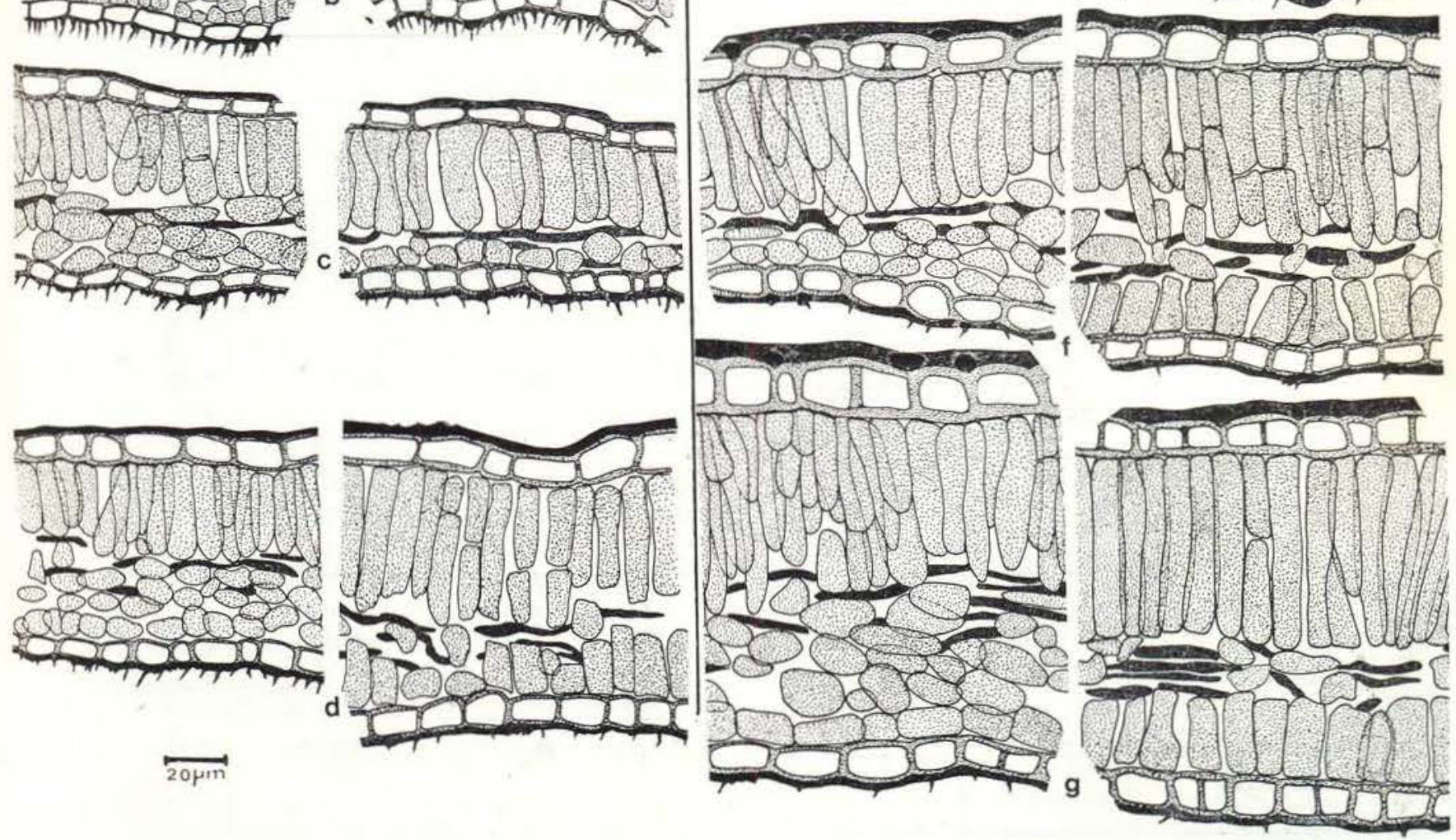

Fig. 9 - Comparação de lâminas de plantas de várzea (es querda) e terra firme (direita) nas diferentes alturas. A $0,7 \mathrm{~m}$ (plântula); B, $2 \mathrm{~m} ; \mathrm{C}, 4 \mathrm{~m} ; \mathrm{D}, 6 \mathrm{~m} ; \mathrm{E}, 8 \mathrm{~m} ; \mathrm{F}, 10 \mathrm{~m} ; \mathrm{G}, 15 \mathrm{~m}$. 
TABELA 10 - Área das células paliçádicas. Resultados dos testes de probabilidades comparando diferentes alturas em um mesmo habitat (várzea ou terra firme) e alturas correspondentes dos dois habitats.

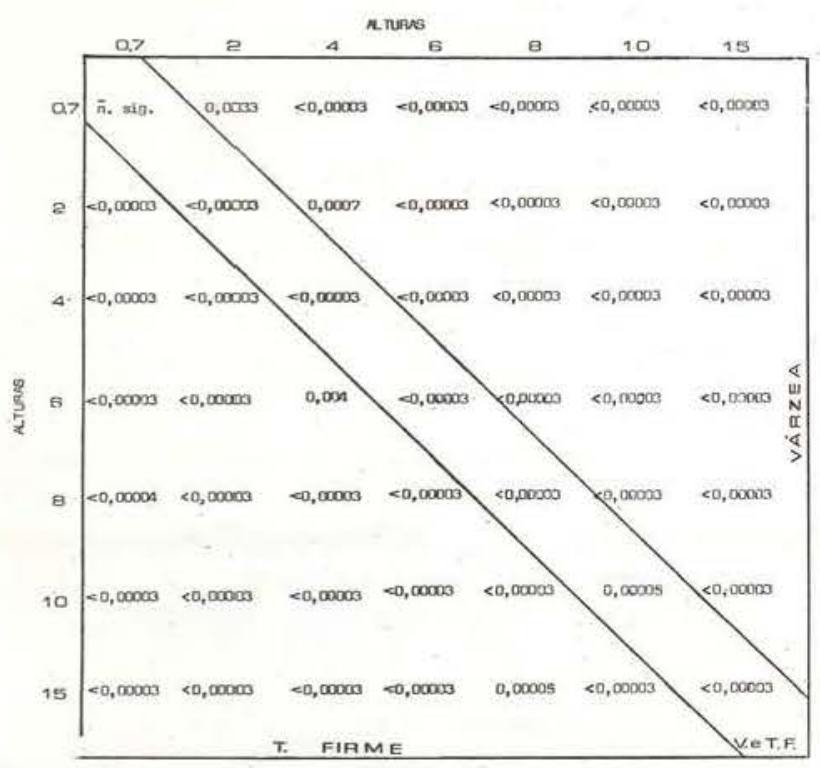

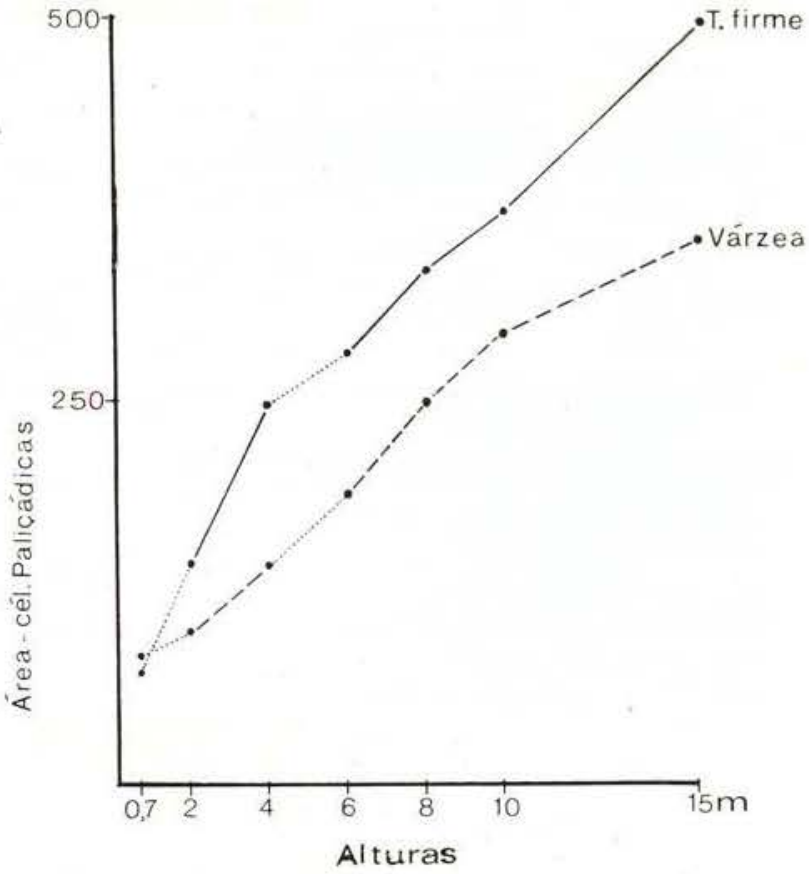

Fig. 10 - Área média em $\mu \mathrm{m}^{2}$ das células paliçádicas (em corte transversal) nas diferentes alturas em plantas de várzea e terra firme.

TABELA 11 - Percentagens médias dos tecidos da lâmina fcliolar nas diferentes alturas em plantas de várzea e ter ra firme.

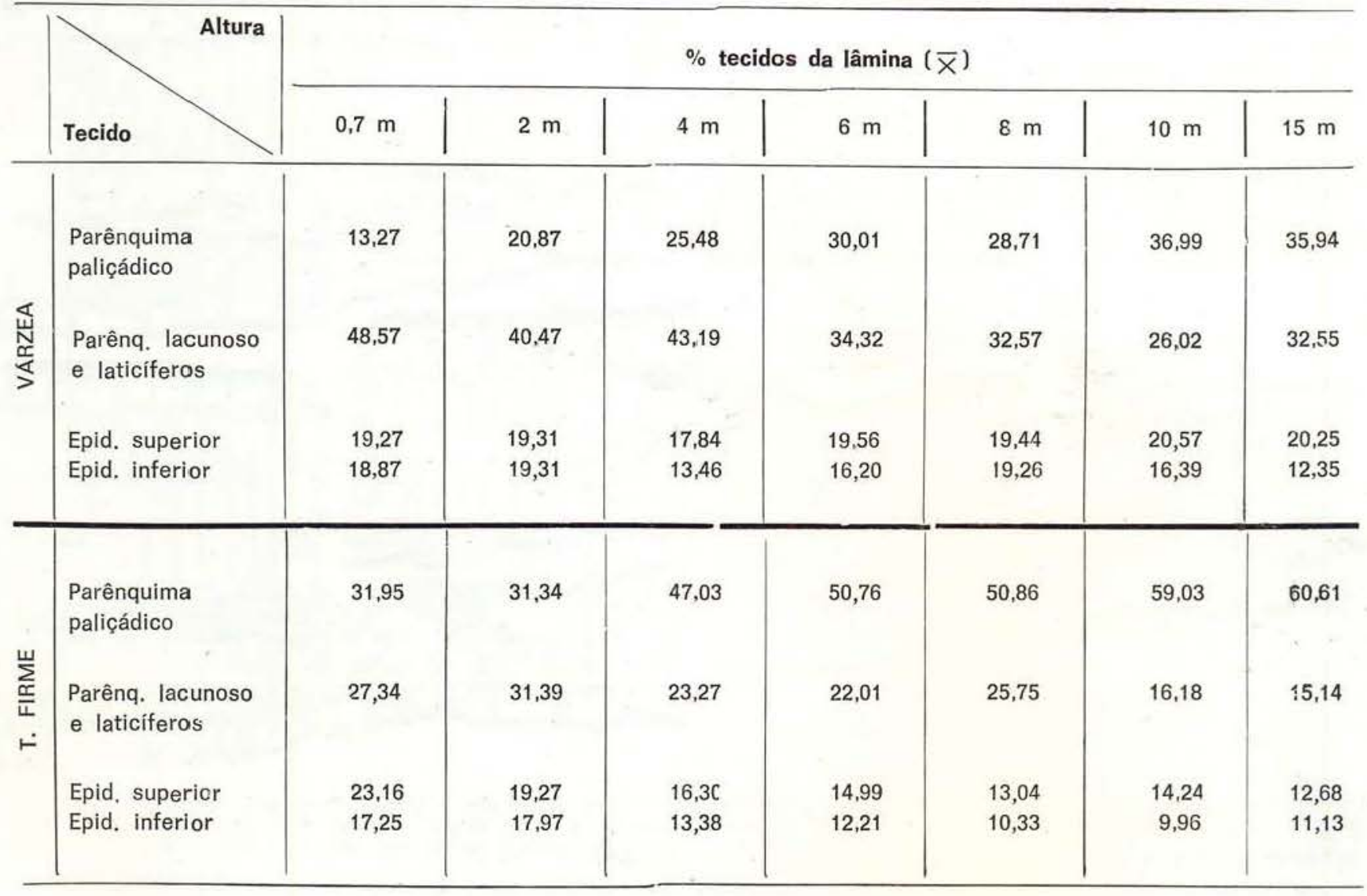


as células epidérmicas em várzea apresentam perímetro superficial estatisticamente mais elevado que em terra firme (Tab. 13 e 14; Fig. 14 e 15).
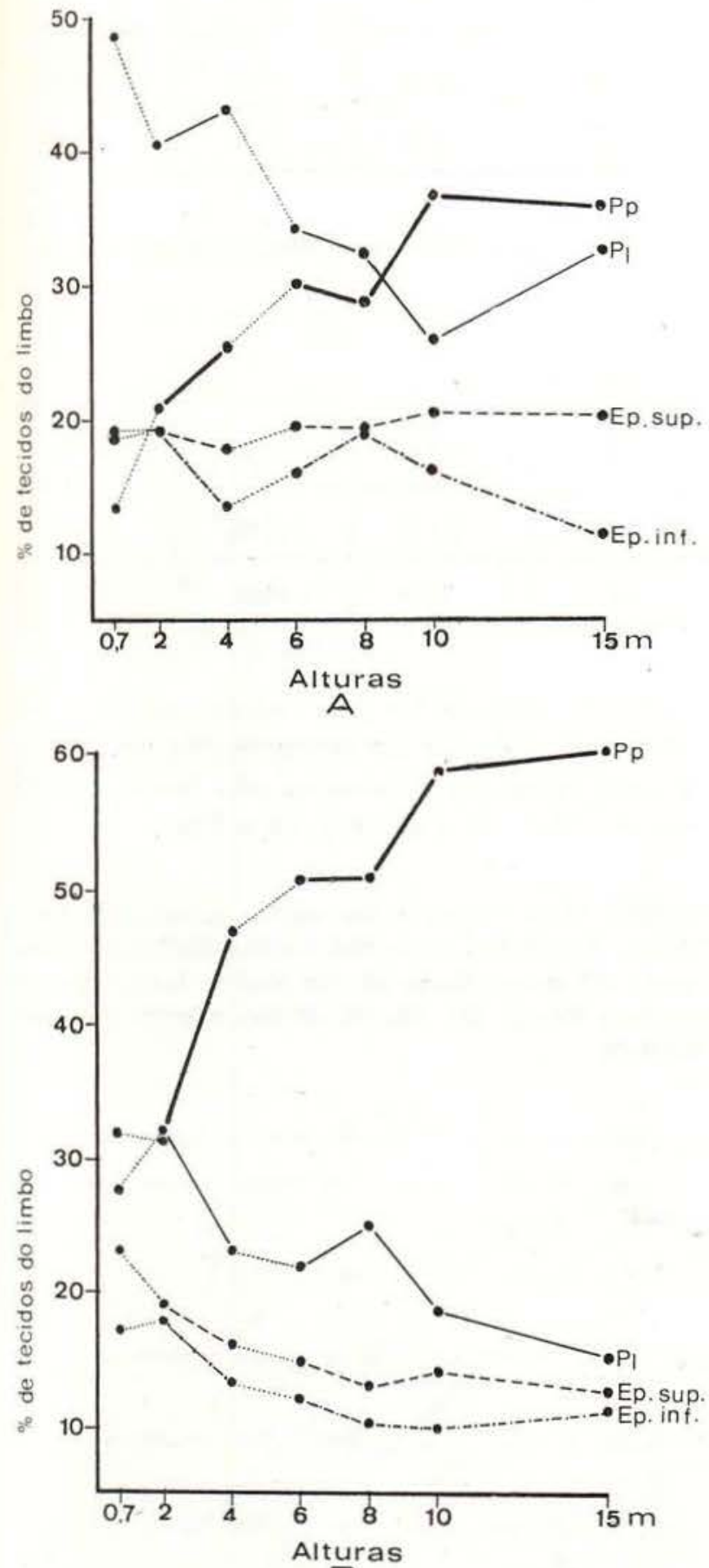

曰

Fig. 11 - Percentagens médias de tecidos da lâmina em plantas de várzea $(A)$ e terra firme $(B)$ nas diferentes alturas. $\mathrm{Pp}$ - parênquima paliçádico; $\mathrm{PI}$ - parênquima lacunoso; Ep - epiderme superior e inferior.
Em vista superficial, as epidermes infe. riores dos folíolos de plantas de várzea e de terra firme apresentam variações similares às das epidermes superiores. A 0.7, 2 e 4 metros, as células são de formas irregulares, per. dendo gradualmente a sinuosidade e tornan-

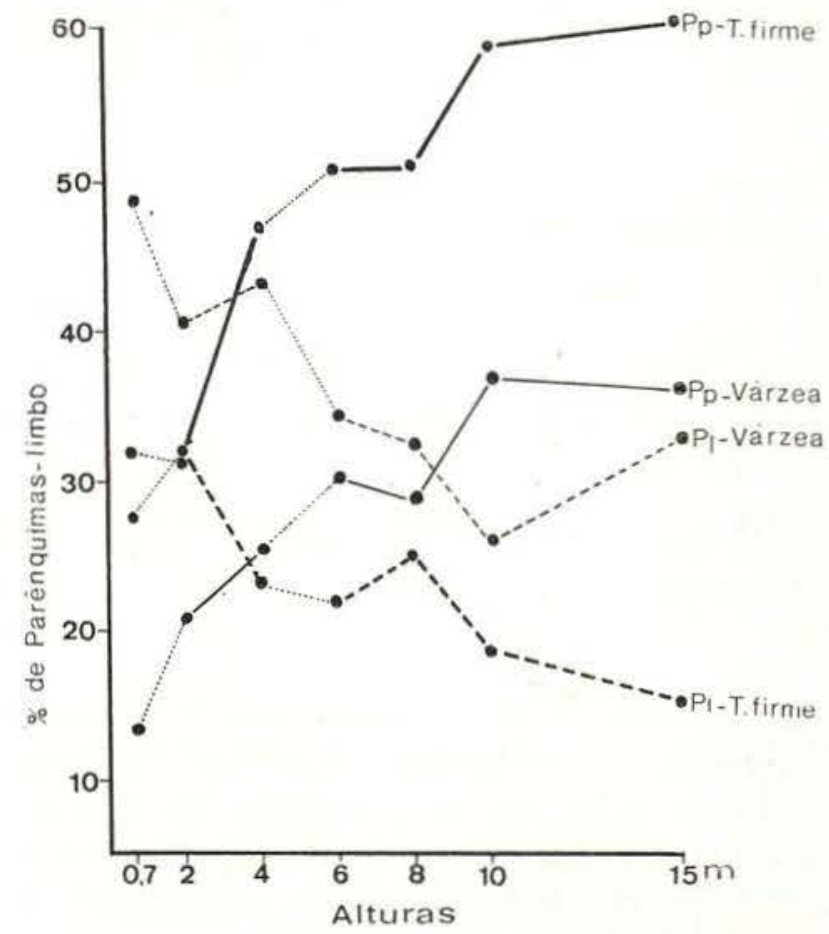

Fig. 12 - Percentagens correlativas de parênquima paliçádico e lacunoso nas diferentes alturas em plantas de várzea e terra firme. $\mathrm{Pp}-$ parênquima paliçádico: $\mathrm{PI}$ - parênquima lacunoso.

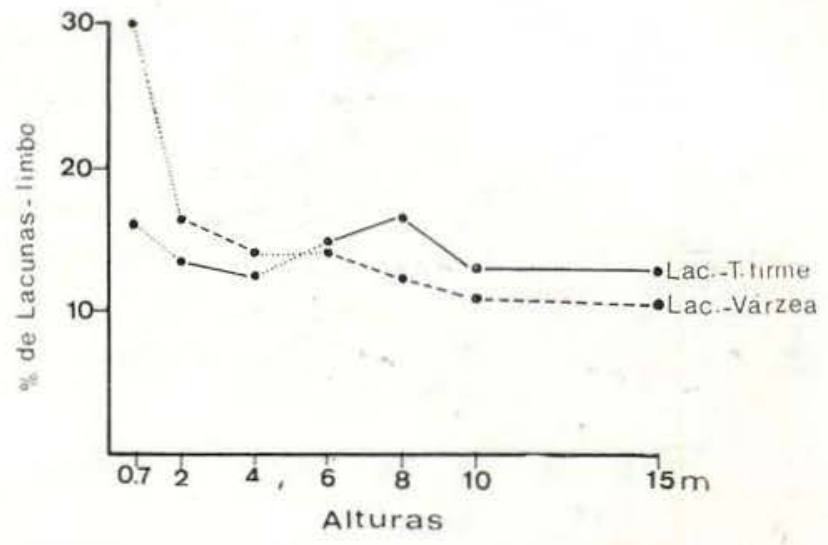

Fig. 13 - Percentagens correlativas de lacunas nas dlferentes alturas em plantas de várzea e terra firme. Lac - Lacunas. 
TABELA 12 - Percentagens médias de lacunas da lâmina foliolar nas diferentes alturas em plantas de várzea e ter ra firme.

\begin{tabular}{|c|c|c|c|c|c|c|c|}
\hline \multirow[b]{2}{*}{ Habitat } & \multicolumn{6}{|c|}{$\%$ de lacunas $(\bar{x})$} & \multirow{2}{*}{$15 \mathrm{~m}$} \\
\hline & $0,7 \mathrm{~m}$ & $2 \mathrm{~m}$ & $4 \mathrm{~m}$ & $6 \mathrm{~m}$ & $8 \mathrm{~m}$ & $10 \mathrm{~m}$ & \\
\hline Terra firme & 30,11 & 16,43 & 14,14 & 14,24 & 12,39 & 10,96 & 10,43 \\
\hline Várzea & 16,28 & 13,74 & 12,52 & 14,80 & 16,64 & 13,18 & 12,88 \\
\hline
\end{tabular}

TABELA 13 - Média dos perimetros das células epidérmicas superiores de folíolos nas diferentes alturas nas plan. tas de várzea e terra firme.

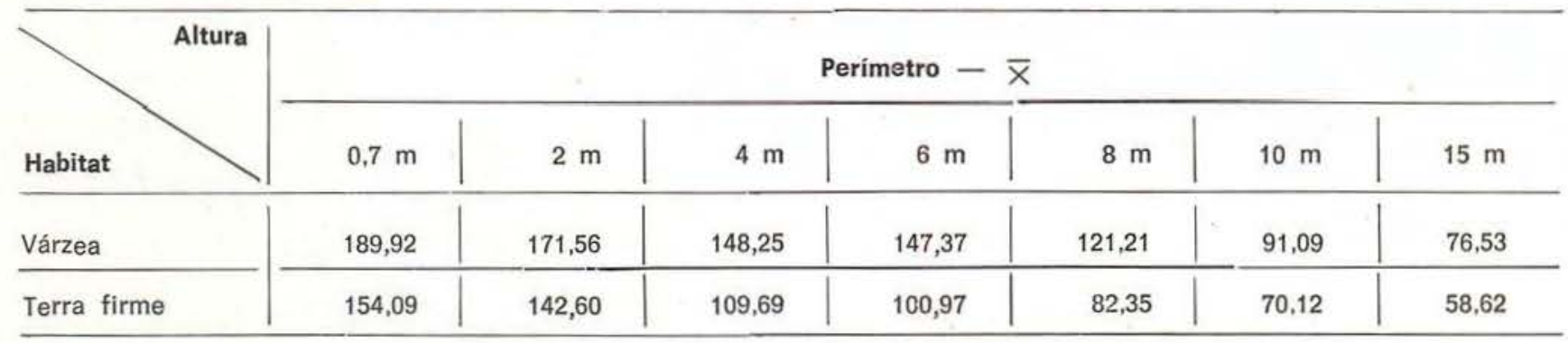

do-se geometricamente definidas a altura de 6 , 8,10 e 15 metros de altura. Também há um espessamento gradual e diminuição do perímetro com a altura, com exceção das células estomáticas que não apresentam diferenças estatisticamente significativas. Ao comparar o

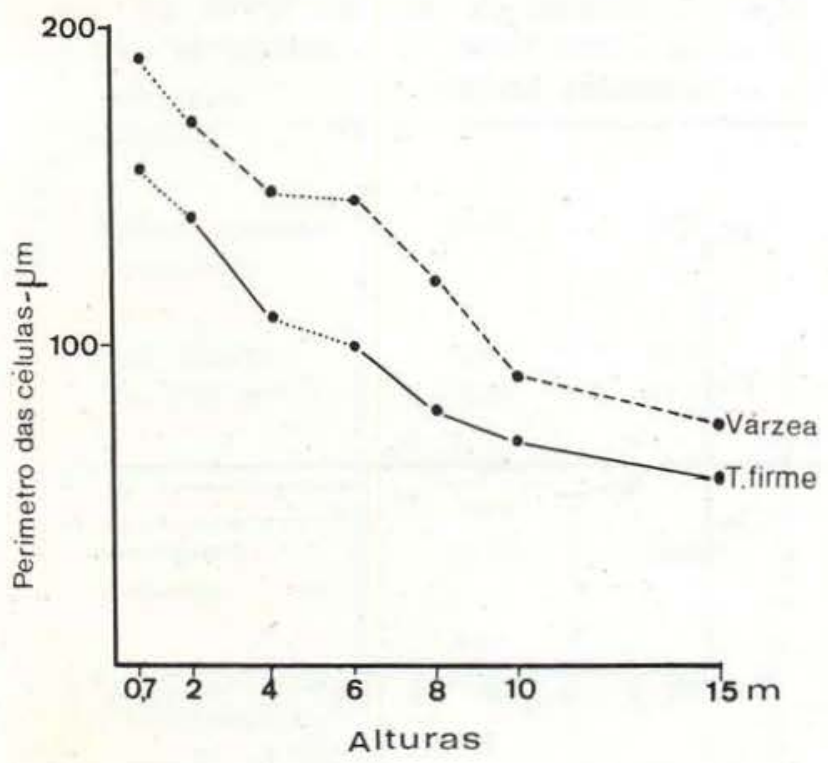

Fig. 14 - Perímetro médio das células epidérmicas superiores em vista superficial nas diferentes alturas em plantas de várzea e terra firme. perímetro superficial das células epidérmicas inferiores a alturas correspondentes em várzea e terra firme, as diferenças não foram significativas (Tab. 15 e 16; Fig. 16 e 17a).

TABELA 14 - Perímetro das células epidérmicas superiores. Resultados dos testes de probabilidades comparando diferentes alturas em um mesmo habitat (várzea ou terra firme) em alturas correspondentes dos dois habitats.

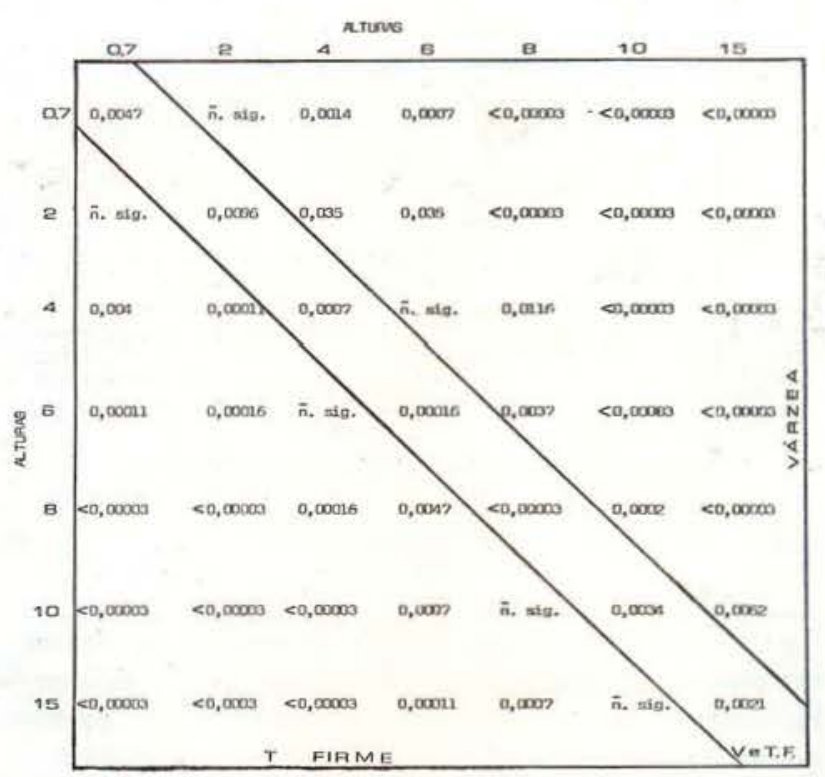


TABELA 15 - Média dos perímetros das células epidérmicas inferiores em vista superficial nas diferentes alturas, em várzea $\mathrm{e}$ terra firme.

\begin{tabular}{|c|c|c|c|c|c|c|c|}
\hline \multirow{2}{*}{ Habitat } & \multicolumn{7}{|c|}{ Perímetro $\bar{x}-(\mu \mathrm{m})$} \\
\hline & $0,7 \mathrm{~m}$ & $2 \mathrm{~m}$ & $4 \mathrm{~m}$ & $6 \mathrm{~m}$ & $8 \mathrm{~m}$ & $10 \mathrm{~m}$ & $15 \mathrm{~m}$ \\
\hline Várzea & 183,78 & 175,33 & 136,70 & 126,15 & 109,52 & 90,96 & 85,07 \\
\hline Terra firme & 174,43 & 162,59 & 135,80 & 122,01 & 96,76 & 85,75 & 82,25 \\
\hline
\end{tabular}
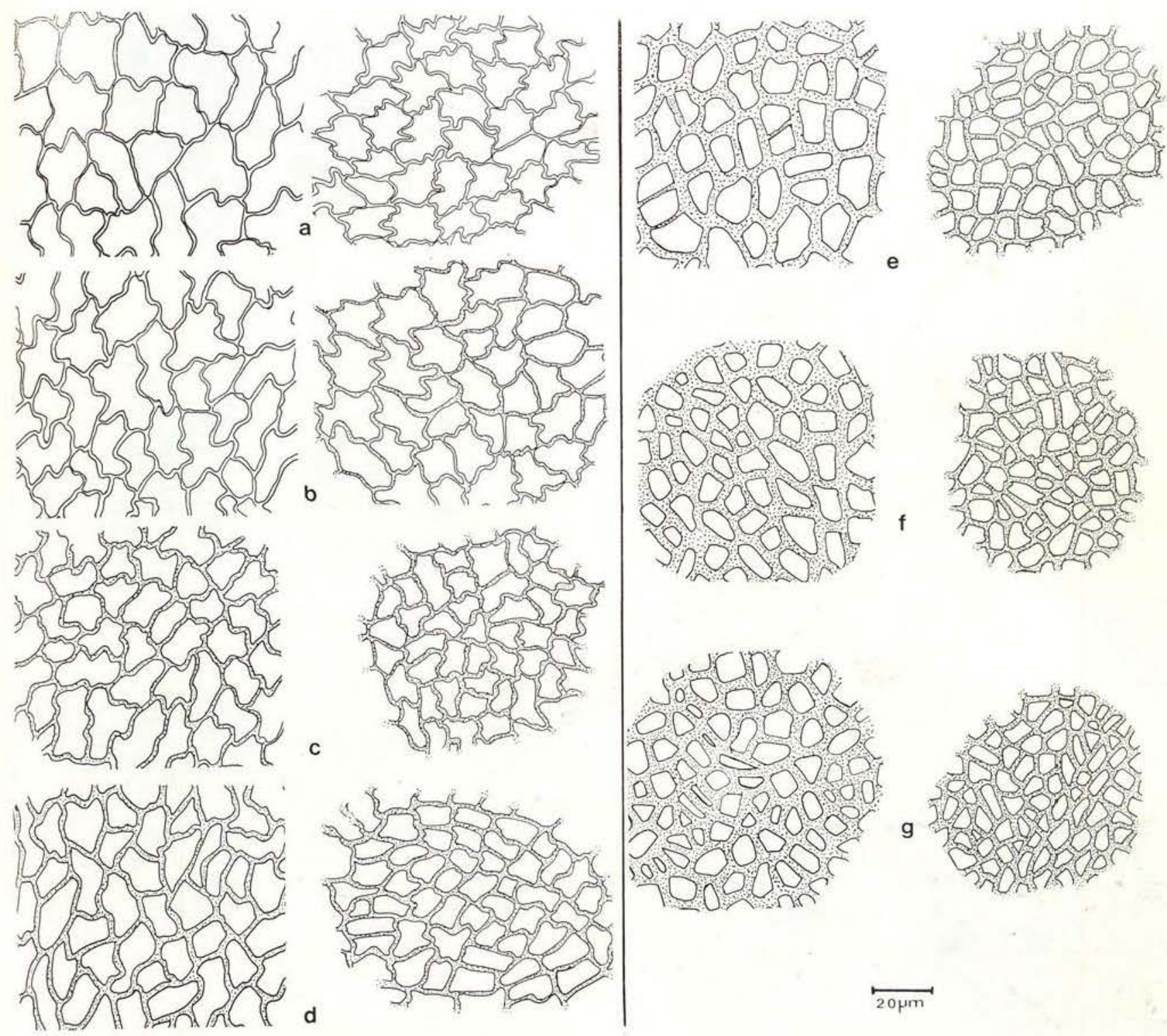

Fig. 15 - Comparação de epidermes superiores de plantas de várzea e terra firme a diferentes alturas. $A, 0,7 \mathrm{~m}$ : $\mathrm{B}, 4 \mathrm{~m} ; \mathrm{D}, 6 \mathrm{~m} ; \mathrm{E}, 8 \mathrm{~m} ; \mathrm{F}, 10 \mathrm{~m} ; \mathrm{G}, 15 \mathrm{~m}$. A esquerda, vár zea; à direita, terra firme. 
O número de estômatos aumenta significativamente com a altura dos folíolos, tanto em várzea quanto em terra firme, sendo significativamente maior no segundo habitat ao comparar folíolos em estratos correspondentes (Tab. 17 e 18; Fig. 16 e 17B).

VENAÇÃo

A venação aumenta com a altura do folíolo na planta tanto em várzea quanto em terra firme, sendo que o folíolo de terra firme possui mais veias por unidade de área (Fig. 18).
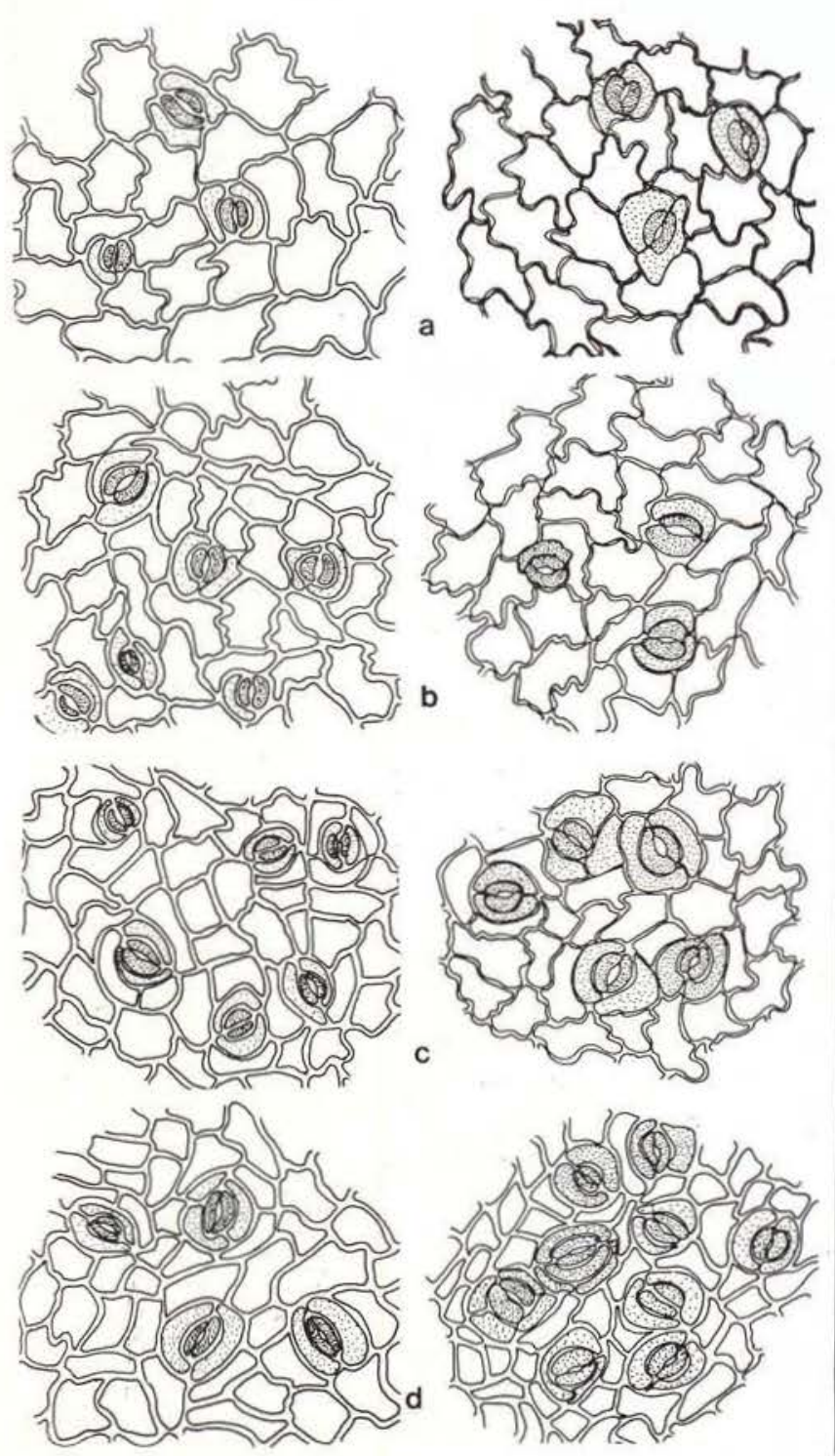
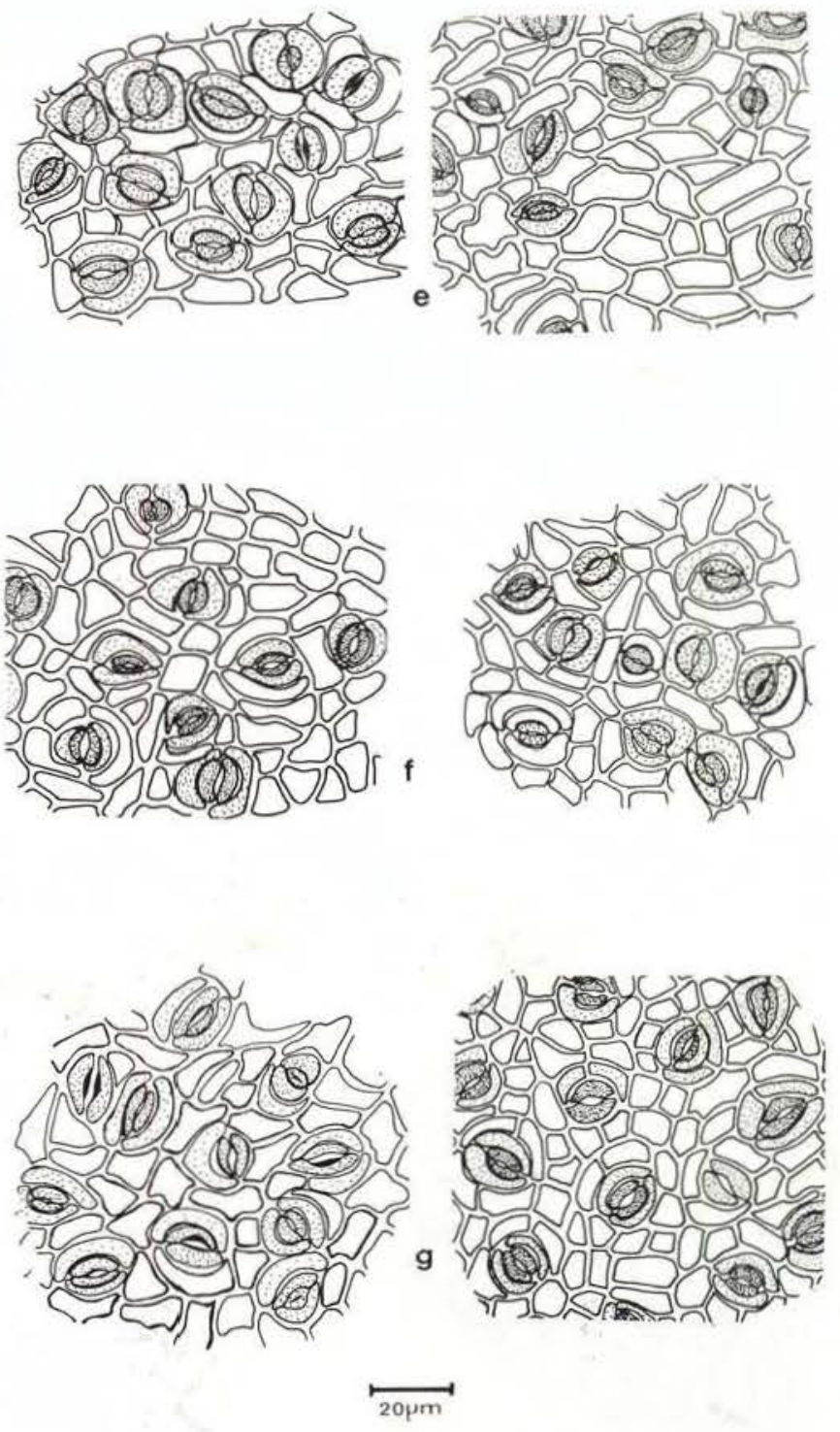

Fig. 16 - Comparação de epidermes inferiores de plantas de várzea e terra firme nas diferentes aituras. A, $0,7 \mathrm{~m}$. C, $4 \mathrm{~m} ; \mathrm{D}, 6 \mathrm{~m} ; \mathrm{E}, 8 \mathrm{~m} ; \mathrm{F}, 10 \mathrm{~m} ; \mathrm{G}, 15 \mathrm{~m}$. Esquerda, várzea direita, terra firme. 

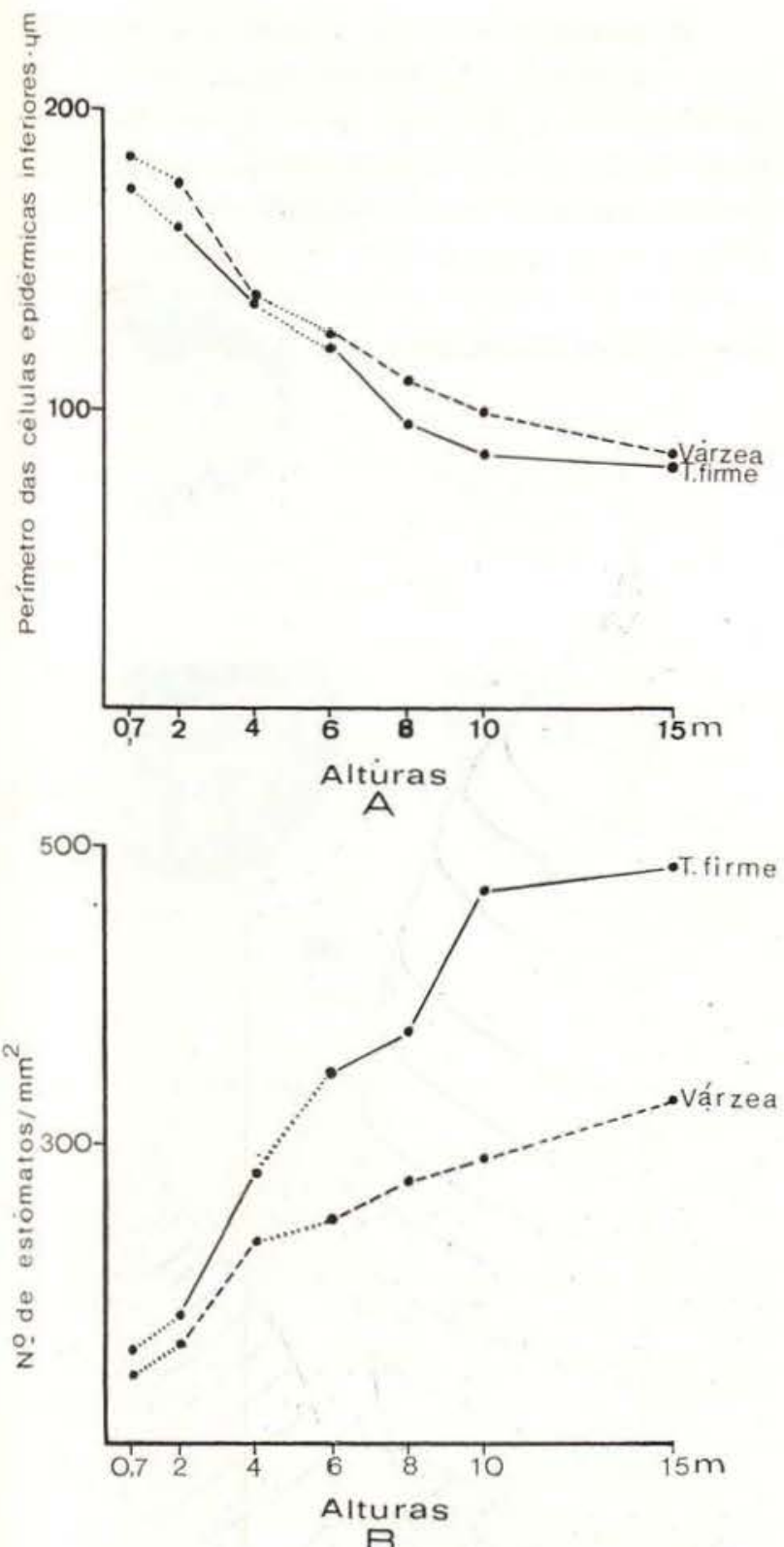

Fig. 17 - Comparação de epidermes inferiores em várzea e terra firme a diversas alturas. A, perimetro médio das células epidérmicas em vista superficial. B, número de estômatos.
TABELA 16 - Perímetro das células epidérmicas inferiores. Resultados dos testes de probabilidades compa. rando diferentes alturas em um mesmo habitat (várzea ou terra firme) e alkuras correspondentes dos dois habitats.

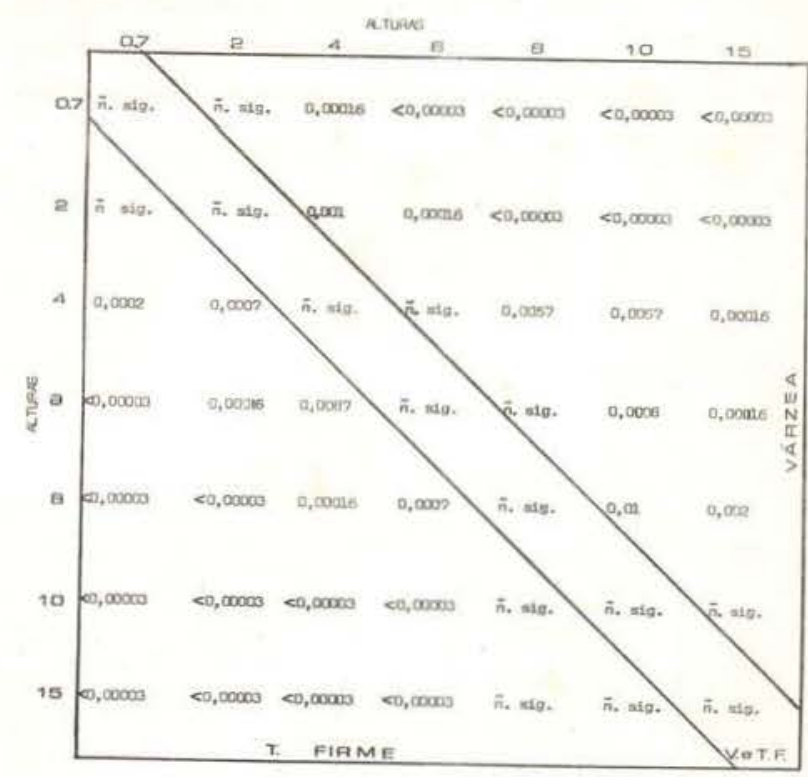

parênquima medular. Os tecidos xilemáticos e de sustentação são os que apresentam aumento a maior altura. O tecido floemático (incluindo laticíferos) e parênquima cortical (incluindo epiderme) apresentam um pequeno aumento em percentagem a maior altura, sendo que o parênquima medular diminui gradativamente (Tab. 19 e 20; Fig. 20).

\section{TECIDOS CONDUTORES}

As percentagens de xilema em pecíolo, nas plantas de várzea diminuem com a altura, sendo ligeiramente maiores a 2, 4, 6 e 8 me-

TABELA 17 - Número médio de estômatos das epidermes inferiores nas diferentes alturas em plantas de várzea e terra firme.

\begin{tabular}{|c|c|c|c|c|c|c|c|}
\hline \multirow[b]{2}{*}{ Habitat } & & & \multicolumn{3}{|c|}{ Estômatos $\bar{x}\left(\mathrm{~mm}^{2}\right)$} & & \\
\hline & $0.7 \mathrm{~m}$ & $2 \mathrm{~m}$ & $4 \mathrm{~m}$ & $6 \mathrm{~m}$ & $8 \mathrm{~m}$ & $10 \mathrm{~m}$ & $15 \mathrm{~m}$ \\
\hline Várzea & 144,2 & 176,0 & 235,3 & 249,2 & 275,8 & 291.7 & 331,0 \\
\hline Terra firme & 162,9 & 183,6 & 281,0 & 347,3 & 372,4 & 471,0 & 487,3 \\
\hline
\end{tabular}

Aspectos... 
tros e menores a 10 e 15 metros. Em terra firme, as percentagens de xilema variam de maneira semelhante à da várzea (Tab. 21; Fig. 7).

A percentagem de tecido xilemático na nervura central aumenta com a altura dos folíolos tanto em várzea quanto em terra firme, sendo ligeiramente maior em terra firme (Tab. 22; Fig. 20).
A comparação das freqüências e diâmetros dos vasos xilemáticos em pecíolc e nervura central a diversas alturas nos dois habitats, revela que estes aumentam significativamente com a altura. A freqüência de vasos, a alturas correspondentes, é significativamente maior em pecíolos ou nervura central de plantas de terra firme, enquanto o diâmetro nos pe-

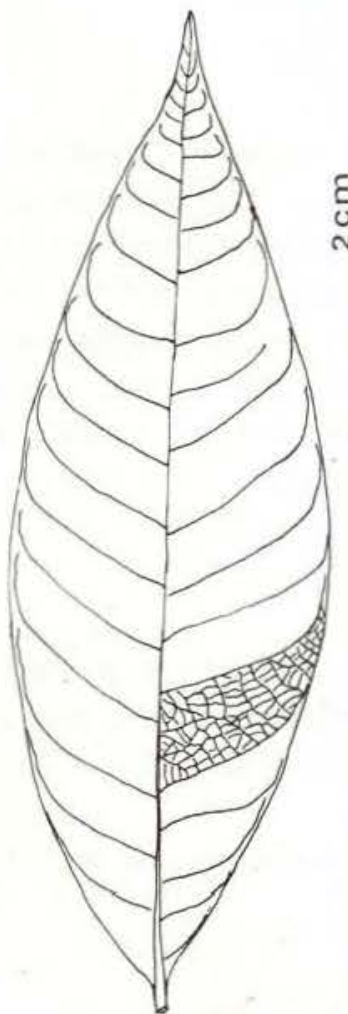

A

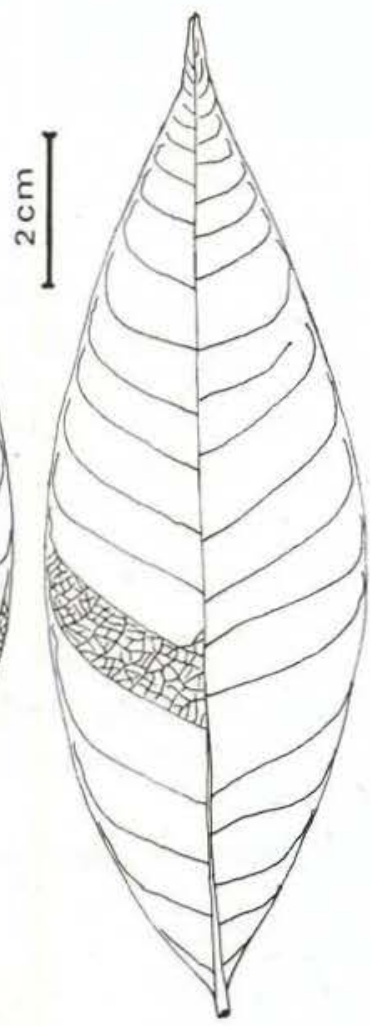

B
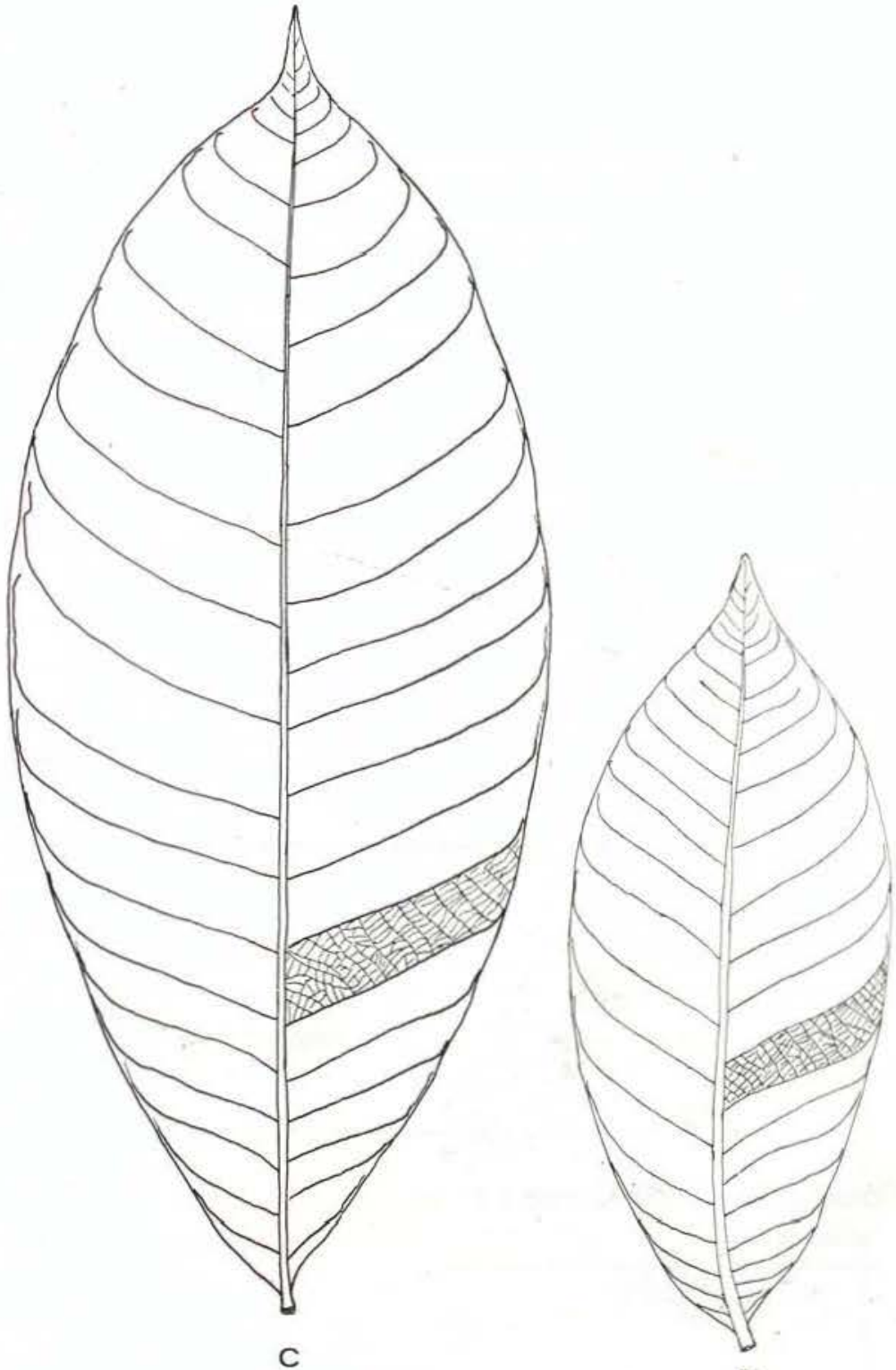

D

Fig. 18 - Comparação dos sistemas de venação em folíolos de plantas de várzea $(A$ e $C$ ) e de terra firme (B e $D)$. A.B, $0,7 \mathrm{~m}$ (plântula); C-D, $15 \mathrm{~m}$. 


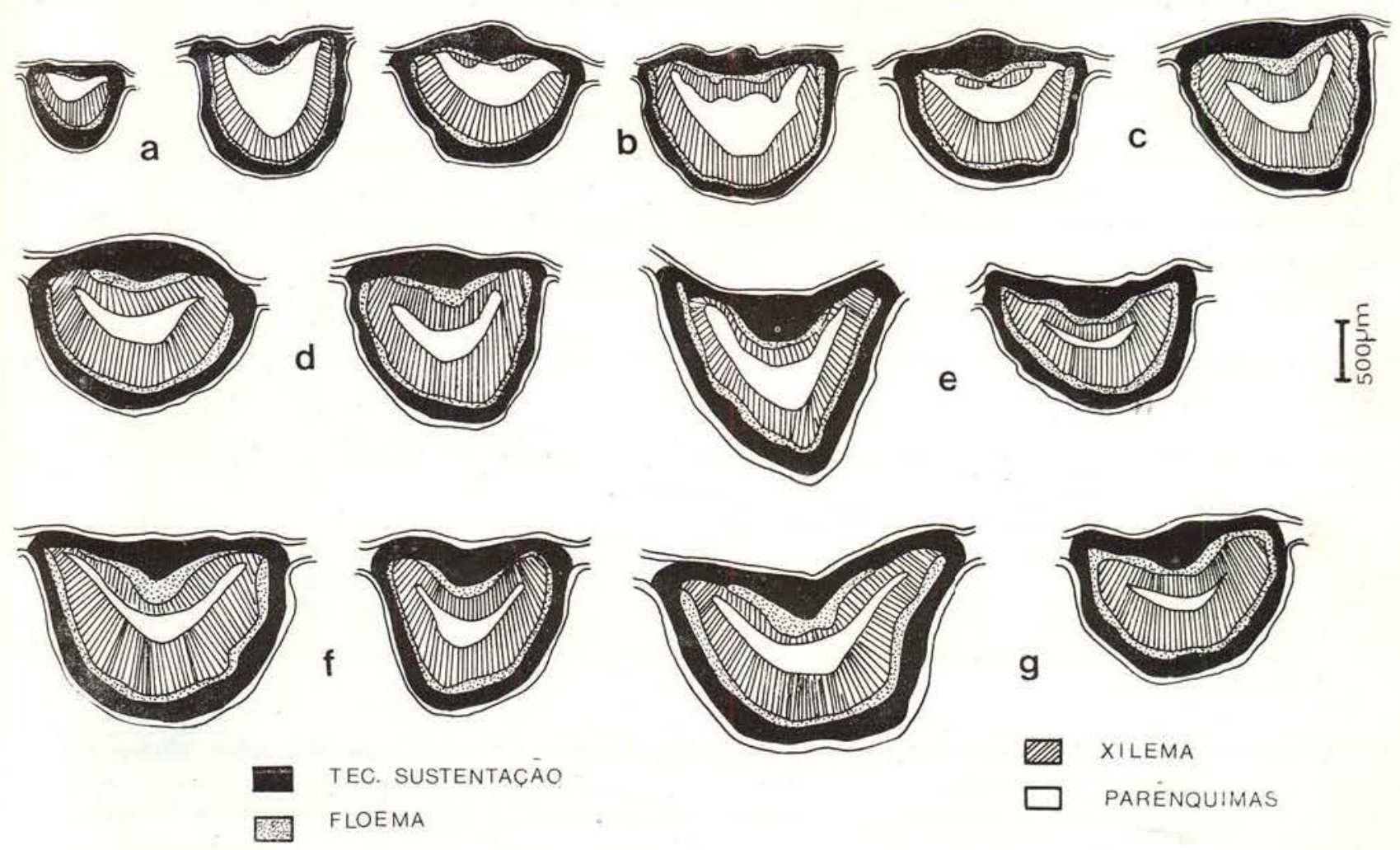

Fig. 19 - Comparação der nervuras centrais em plantas de várzea e terra firme nas diferentes alturas. A, 0,7 m; $\mathrm{B}, 2 \mathrm{~m} ; \mathrm{C}, 4 \mathrm{~m} ; \mathrm{D}, 6 \mathrm{~m} ; \mathrm{E}, 8 \mathrm{~m} ; \mathrm{F}, 10 \mathrm{~m} ; \mathrm{G}, 15 \mathrm{~m}$. Esquerda, várzea; direita, terra firme.

cíolos é significativamente menor, não sendo significativos em nervura central ao comparar várzea e terra firme (Tab. 23, 24, 25, 26 e 27; Fig. 21 e 22).

O tecido floemático aumenta gradativamente com a elevação da folha na planta, tanto em várzea quanto em terra firme. Os pecíolos e nervuras de plantas de várzea, em geral apresentam maior percentagem de floema que os pecíolos e nervuras centrais das plantas de terra firme (Tab. 28). As percentagens de tecido floemático é muito inferior às dos tecidos xilemáticos em todas as alturas e nos dois habitats (Fig. 23).

\section{TECIDO DE SUSTENTAÇÃo}

O estudo de pecíolos e nervuras centrais dos folíolos revela um aumento gradual nas percentagens de tecidos de sustentação com a altura da folha na planta, tanto em várzea quan-
TABELA 18 - Número de estômatos. Resultados dos testes de probabilidades comparando diferentes alturas em um mesmo habitat (várzea ou terra firme) e alturas correspondentes dos dois habitats.

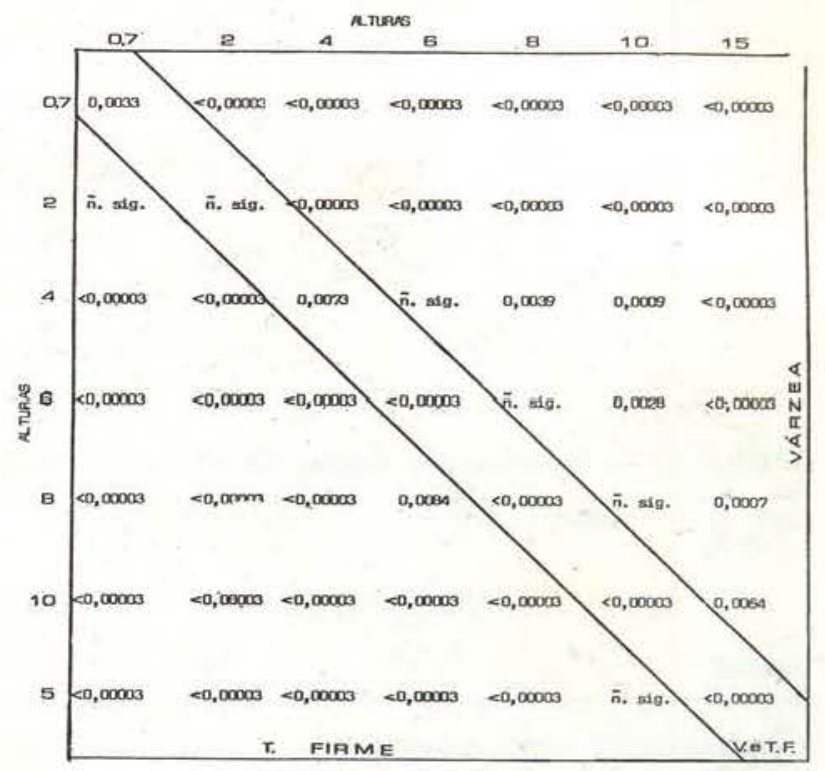


TABELA 19 - Percentagens médias dos tecidos componentes da nervura central nas diferentes alturas em plantas de várzea.

\begin{tabular}{|c|c|c|c|c|c|c|c|}
\hline \multirow[b]{2}{*}{ Tecido } & \multicolumn{7}{|c|}{$\%$ de Tecidos $-\bar{x}$} \\
\hline & $0,7 \mathrm{~m}$ & $2 \mathrm{~m}$ & $4 \mathrm{~m}$ & $6 \mathrm{~m}$ & $8 \mathrm{~m}$ & $10 \mathrm{~m}$ & $15 \mathrm{~m}$ \\
\hline $\begin{array}{l}\text { Parênq. Cortical } \\
\text { e epiderme }\end{array}$ & 12,72 & 13,24 & 13,20 & 11,61 & 15,57 & 15,00 & 13,77 \\
\hline $\begin{array}{l}\text { Tecido sustenta- } \\
\text { çăo }\end{array}$ & 31,00 & 23,99 & 29,03 & 28,33 & 33,76 & 31,31 & 31,80 \\
\hline $\begin{array}{l}\text { Floema e Latici- } \\
\text { feros }\end{array}$ & 8,41 & 11,30 & 10,60 & 14,41 & 14,82 & 19,95 & 13,25 \\
\hline Xilema & 18,86 & 29,18 & 30,70 & 33,50 & 30,42 & 32,80 & 35,43 \\
\hline Parênq. medular & 28,97 & 22,47 & 17,17 & 12,13 & 7,41 & 5,92 & 5.74 \\
\hline
\end{tabular}

TABELA 20 - Percentagens médias dos tecidos componentes da nervura central nas diferentes alturas em plantas de terra firme.

\begin{tabular}{|c|c|c|c|c|c|c|c|}
\hline \multirow[b]{2}{*}{ Tecido } & \multicolumn{7}{|c|}{$\%$ de Tecidos $-\bar{x}$} \\
\hline & $0,7 \mathrm{~m}$ & $2 \mathrm{~m}$ & $4 \mathrm{~m}$ & $6 \mathrm{~m}$ & $8 \mathrm{~m}$ & $10 \mathrm{~m}$ & $15 \mathrm{~m}$ \\
\hline $\begin{array}{l}\text { Parênquima Cor- } \\
\text { tical e epiderme }\end{array}$ & 6,23 & 6,00 & 8,88 & 10,00 & 10,44 & 12,79 & 10,40 \\
\hline $\begin{array}{l}\text { Tecido sustenta- } \\
\text { ção }\end{array}$ & 26,60 & 23,30 & 29,96 & 35,22 & 34,50 & 34,40 & 35,40 \\
\hline $\begin{array}{l}\text { Floema e Latici- } \\
\text { feros }\end{array}$ & 7,33 & 7,76 & 9,89 & 10,85 & 11,34 & 13,82 & 12,16 \\
\hline Xilema & 31,54 & 40,60 & 43,32 & 38,10 & 38,33 & 37,51 & 40,90 \\
\hline $\begin{array}{l}\text { Parênquima me- } \\
\text { dular }\end{array}$ & 28,23 & 22,30 & 10,00 & 5,75 & 5,12 & 1,64 & 1,11 \\
\hline
\end{tabular}

TABELA 21 - Percentagens médias de xilema em peciolo nas diferentes alturas em plantas de várzea e terra firme.

\begin{tabular}{|c|c|c|c|c|c|c|c|}
\hline \multirow[b]{2}{*}{ Habitat } & \multicolumn{6}{|c|}{$\%$ de xilema $(\bar{x})$} & \multirow{2}{*}{$15 \mathrm{~m}$} \\
\hline & $0,7 \mathrm{~m}$ & $2 \mathrm{~m}$ & $4 \mathrm{~m}$ & $6 \mathrm{~m}$ & $8 \mathrm{~m}$ & $10 \mathrm{~m}$ & \\
\hline Várzea & 41,38 & 44,84 & 42,68 & 41,71 & 42,22 & 35,73 & 35,03 \\
\hline Terra firme & 40,46 & 48,07 & 49,81 & 41,31 & 40,31 & 43,11 & 43,90 \\
\hline
\end{tabular}




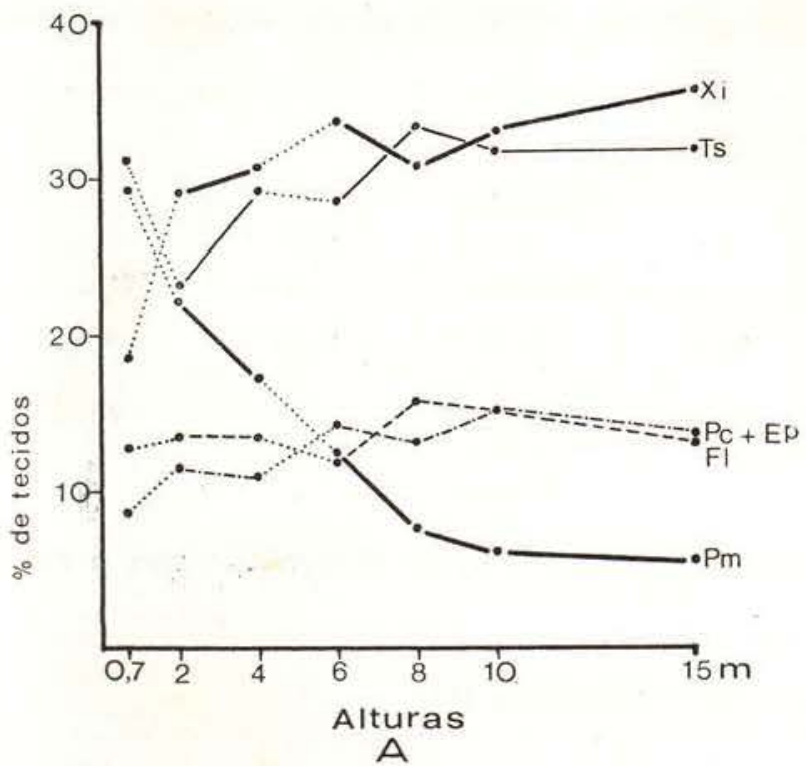

A espessura da parede das células de sus. tentação aumenta significativamente com a altura da folha na planta, tanto em várzea quanto em terra firme, sendo as paredes das células de plantas de terra firme significativamen. te mais espessas (Tab. 29 e 30; Fig. 25 e 26).
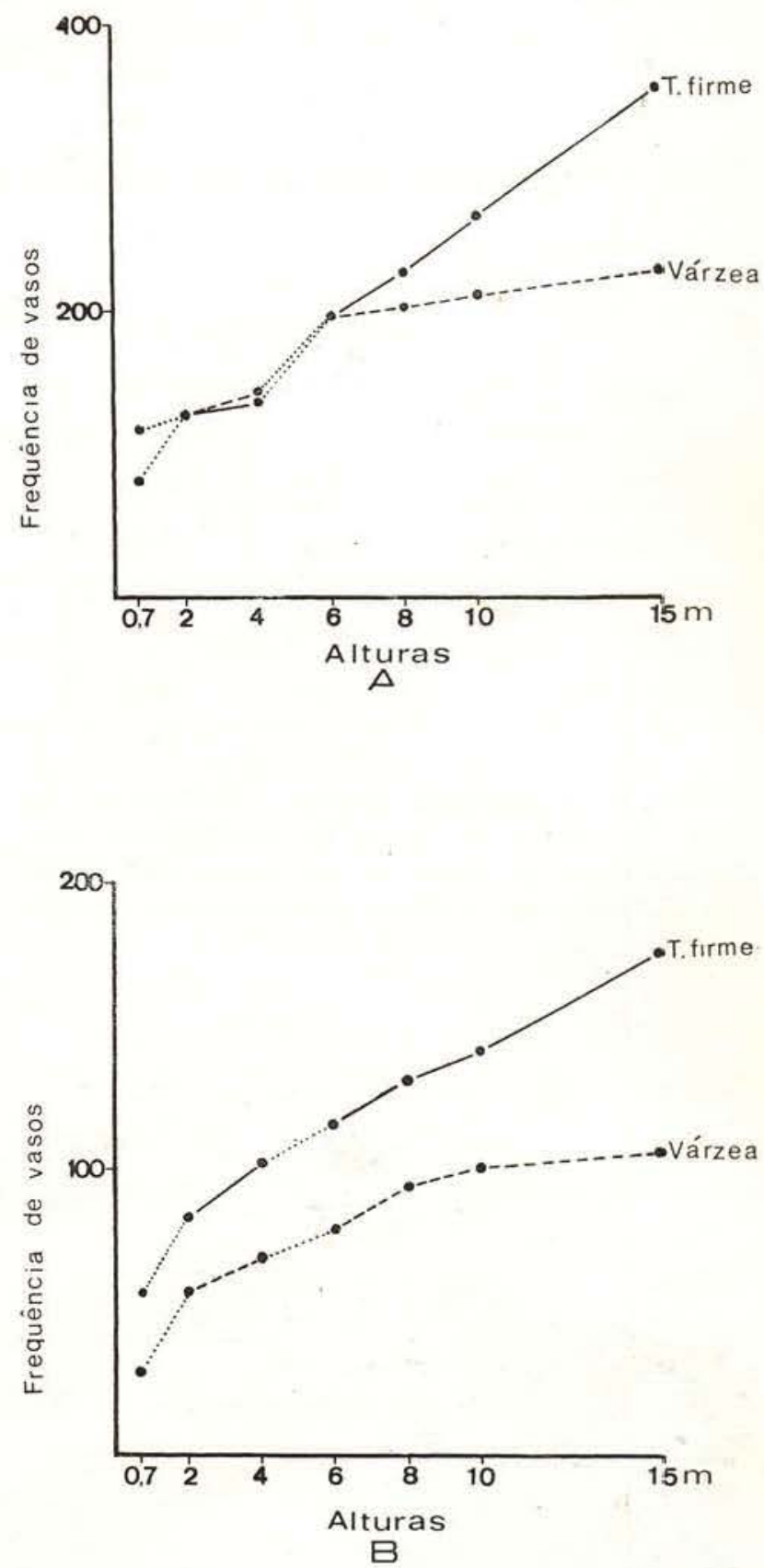

Fig. 21 - Freqüência média de vasos xilemáticos em pecíolos (A) e nervura central (B) nas diferentes alturas em plantas de várzea e terra firme. 
TABELA 22 - Percentagens médias de xilema na nervura central em diferentes alturas em plantas de várzea e terra firme.

\begin{tabular}{|c|c|c|c|c|c|c|c|}
\hline \multirow{2}{*}{ Habitat } & \multicolumn{7}{|c|}{$\%$ de xilema $(\bar{x})$} \\
\hline & $0,7 \mathrm{~m}$ & $2 \mathrm{~m}$ & $4 \mathrm{~m}$ & $6 \mathrm{~m}$ & $8 \mathrm{~m}$ & $10 \mathrm{~m}$ & $15 \mathrm{~m}$ \\
\hline Várzea & 18,86 & 29,18 & 30,70 & 33,50 & 30,42 & 32,80 & 35,43 \\
\hline Terra firme & 31,54 & 40,10 & 43,32 & 38,10 & 38,33 & 37,51 & 40,90 \\
\hline
\end{tabular}

TABELA 23 - Freqüência média de vasos xilemáticos em pecíolo e nervura central em plantas de várzea e terra firme.

\begin{tabular}{|c|c|c|c|c|c|c|c|c|}
\hline \multirow{2}{*}{ 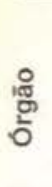 } & \multicolumn{8}{|c|}{ Frequeência de vasos xilemáticos $(\bar{x})$} \\
\hline & Habitat & $0,7 \mathrm{~m}$ & $2 \mathrm{~m}$ & $4 \mathrm{~m}$ & $6 \mathrm{~m}$ & $8 \mathrm{~m}$ & $10 \mathrm{~m}$ & $15 \mathrm{~m}$ \\
\hline \multirow{2}{*}{$\begin{array}{l}\frac{0}{0} \\
\frac{0}{0} \\
0\end{array}$} & Várzea & 82,0 & 132,8 & 141,7 & 199,2 & 200,0 & 209,0 & 223,8 \\
\hline & Terra firme & 117,2 & 120,9 & 134,8 & 195,8 & 224,3 & 263,0 & 350.1 \\
\hline \multirow{2}{*}{ 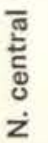 } & Várzea & 28,5 & 57,1 & 68,0 & 78,7 & 94,9 & 100,9 & 106,1 \\
\hline & Terra firme & 51,3 & 83,8 & 102,9 & 115,5 & 131,4 & 141,0 & 174,7 \\
\hline
\end{tabular}

TABELA 24 - Freqüência de vasos xilemáticos em pecíolo. Resultados dos testes de probabilidades comparando diferentes alturas em um mesmo habitat (várzea ou terra firme) e alturas correspondentes dos dois habitats.

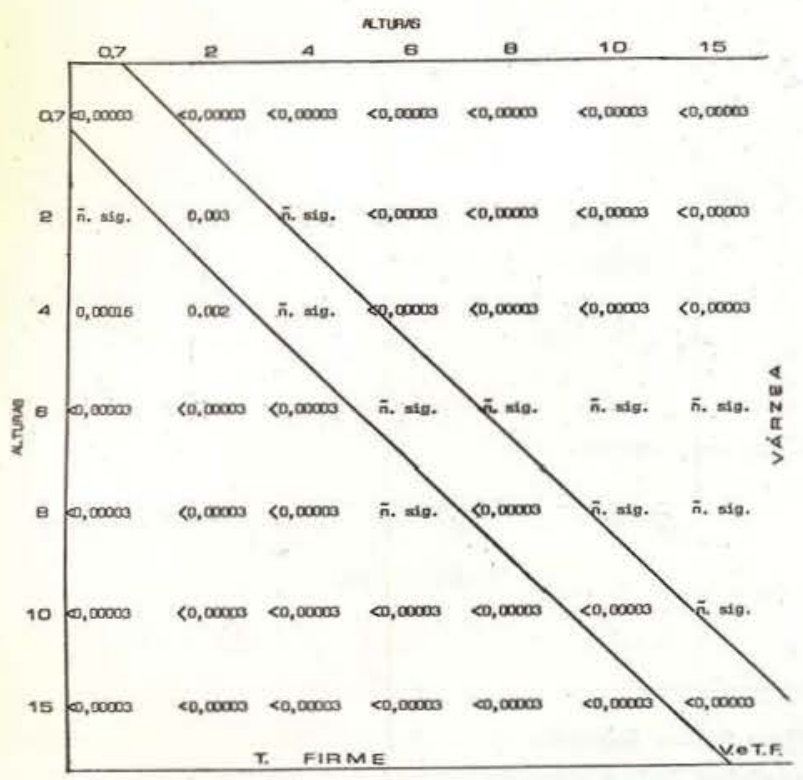

TABELA 25 - Freqüência de vasos xilemáticos em nervura central. Resultados de testes de probabilidades comparando diferentes alturas em um mesmo habitat (várzea ou terra firme) e alturas correspondentes dos cois habitats.

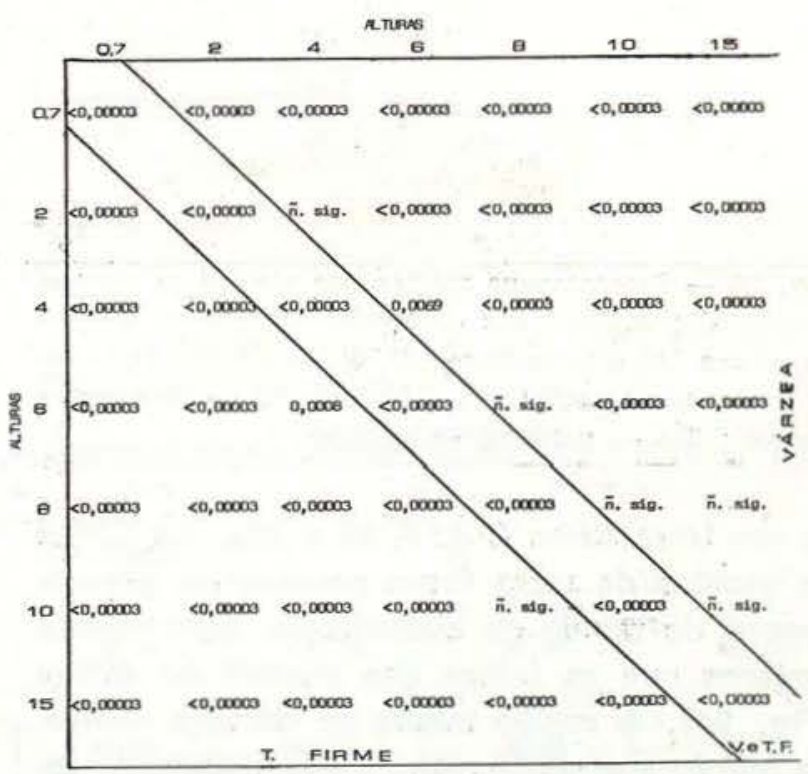


TABELA 26 - Diâmetro médio de vasos xilemáticos em pecíolo e nervura central nas diferentes alturas em plantas ce várzea e terra firme.

\begin{tabular}{|c|c|c|c|c|c|c|c|c|}
\hline \multirow{2}{*}{ 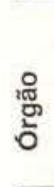 } & \multirow[b]{2}{*}{ Habitat } & & \multicolumn{5}{|c|}{ Diâmetro de vasos xilemáticos $(\bar{x}) \mu \mathrm{m}$} \\
\hline & & $0,7 \mathrm{~m}$ & $2 \mathrm{~m}$ & $4 \mathrm{~m}$ & $6 \mathrm{~m}$ & $8 \mathrm{~m}$ & $10 \mathrm{~m}$ & $15 \mathrm{~m}$ \\
\hline$\div$ & Várzea & 26,47 & 33,79 & 34,91 & 45,51 & 46,63 & 49,99 & 58,31 \\
\hline$\stackrel{0}{0}$ & Terra firme & 27,39 & 29,04 & 36,80 & 37,68 & 41,60 & 44,28 & 50,08 \\
\hline$\underset{\frac{\pi}{\pi}}{\bar{\pi}}$ & Várzea & 22,15 & 27,61 & 28,72 & 29,99 & 31,39 & 35,69 & 40,41 \\
\hline$\underline{z}$ & Terra firme & 21,52 & 25,65 & 24,32 & 28,02 & 31,66 & 32,49 & 36,03 \\
\hline
\end{tabular}

TABELA 27 - Diâmetro do xilema em pecíolo (acima) em nervura central (em baixo). Resultados dos testes de probabilidades comparando diferentes alturas em um mesmo habitat (várzea ou terra firme) e alturas correspondentes dos dois habitats.
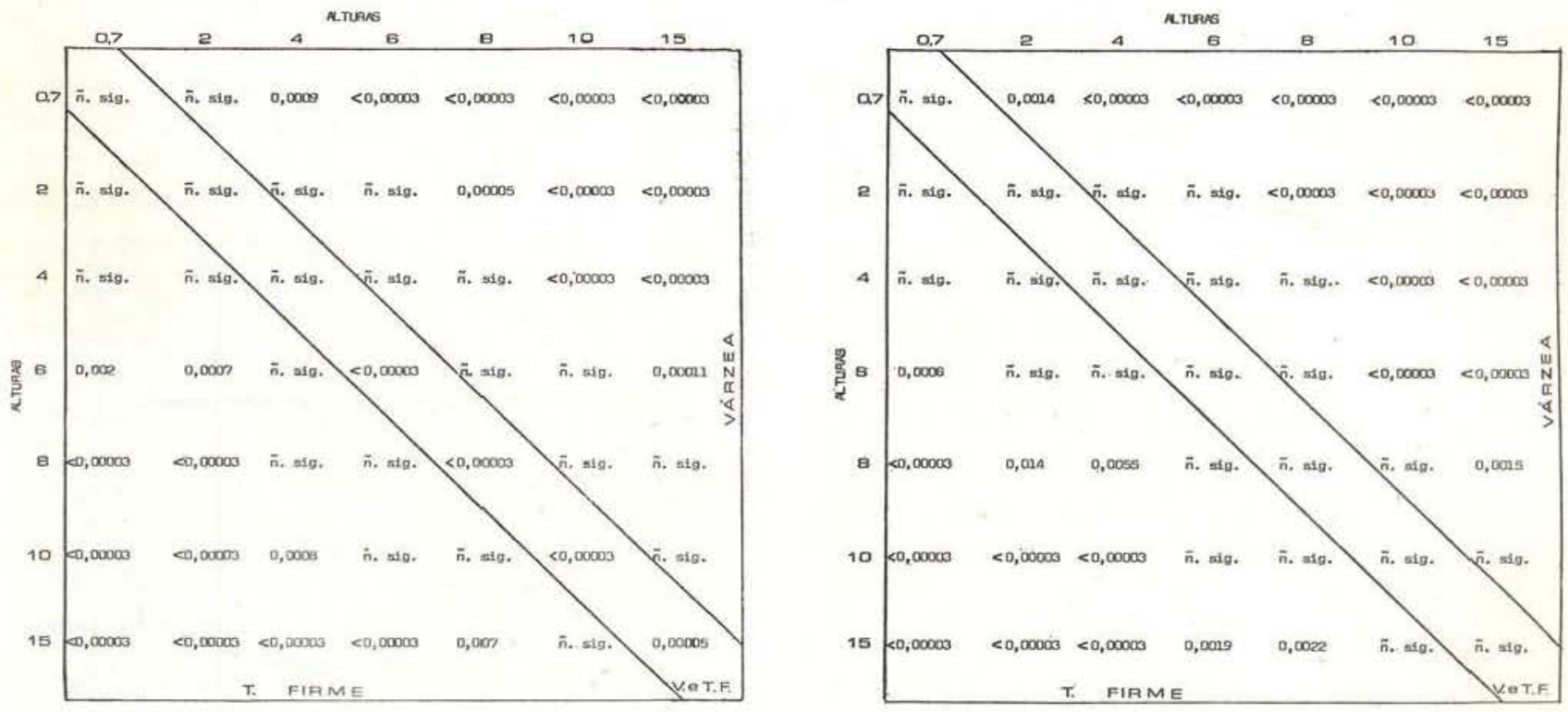

TABELA 28 - Percentagens médias de tecido floemático de pecíolo e nervura central nas diferentes alturas em plantas de várzea e terra firme.

\begin{tabular}{|c|c|c|c|c|c|c|c|c|}
\hline \multirow{2}{*}{ 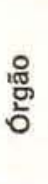 } & \multirow[b]{2}{*}{ Habitat } & \multicolumn{7}{|c|}{$\%$ de tecido floemático $(\bar{x})$} \\
\hline & & $0,7 \mathrm{~m}$ & $2 \mathrm{~m}$ & $4 \mathrm{~m}$ & $6 \mathrm{~m}$ & $8 \mathrm{~m}$ & $10 \mathrm{~m}$ & $15 \mathrm{~m}$ \\
\hline \multirow{2}{*}{$\begin{array}{l}\frac{0}{0} \\
\frac{0}{0} \\
2\end{array}$} & Várzea & 7,93 & 4,56 & 6,24 & 8,04 & 9,59 & 10,97 & 14,82 \\
\hline & Terra firme & 6,52 & 7,34 & 6,70 & 8,50 & 11,33 & 11,84 & 11,00 \\
\hline \multirow{2}{*}{ 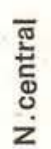 } & Várzea & 8,41 & 11,30 & 10,60 & 14,41 & 12,82 & 14,95 & 13,25 \\
\hline & Terra firme & 7,33 & 7,76 & 9,89 & 10,85 & 11,34 & 13,82 & 12,16 \\
\hline
\end{tabular}

Aspectos. . 
TABELA 29 - Espessura média em $\mu \mathrm{m}$ da parede celular do tecido de sustentação nas diferentes alturas e nos dois habitats.

\begin{tabular}{|c|c|c|c|c|c|c|c|}
\hline \multirow[b]{2}{*}{ Habitat } & \multicolumn{7}{|c|}{ Espessura de paredes $-\bar{x}$} \\
\hline & $0,7 \mathrm{~m}$ & $2 \mathrm{~m}$ & $4 \mathrm{~m}$ & $6 \mathrm{~m}$ & $8 \mathrm{~m}$ & $10 \mathrm{~m}$ & $15 \mathrm{~m}$ \\
\hline Várzea & 2,92 & 3,10 & 3,22 & 4,21 & 4,24 & 4,67 & 4,66 \\
\hline Terra firme & 3,85 & 4,37 & 4,30 & 5,09 & 5,33 & 5,04 & 5,69 \\
\hline
\end{tabular}

TABELA 30 - Espessura de parede. Resultados dos testes de probabilidades comparando diferentes alturas em um mesmo habitat (várzea ou terra firme) e alturas correspondentes dos dols habitats.
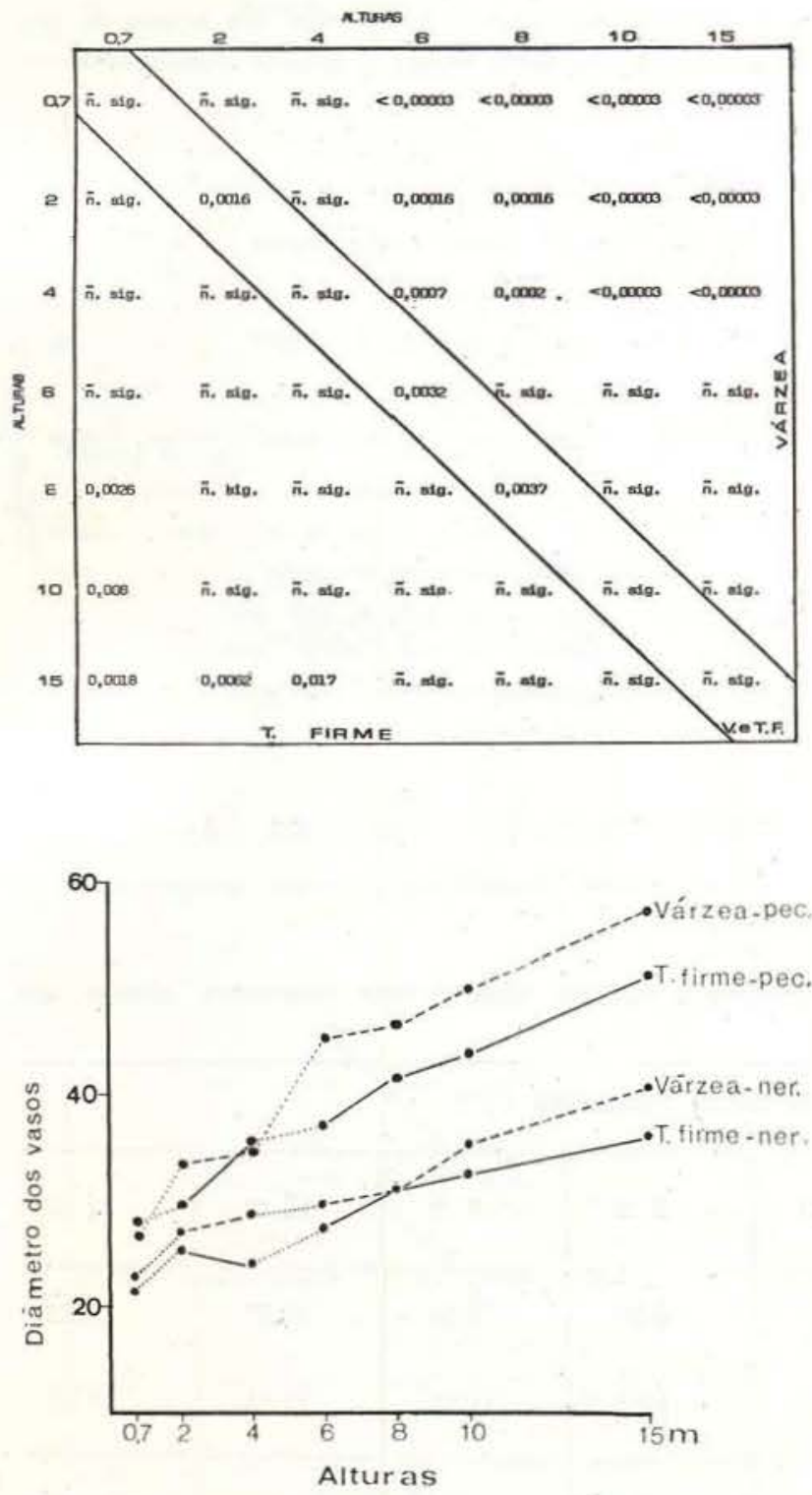

Fig. 22 - Diâmetro em $\mu \mathrm{m}$ dos vasos xilemáticos em pecíolo e nervura central nas diferentes alturas em plantas de várzea e terra firme.
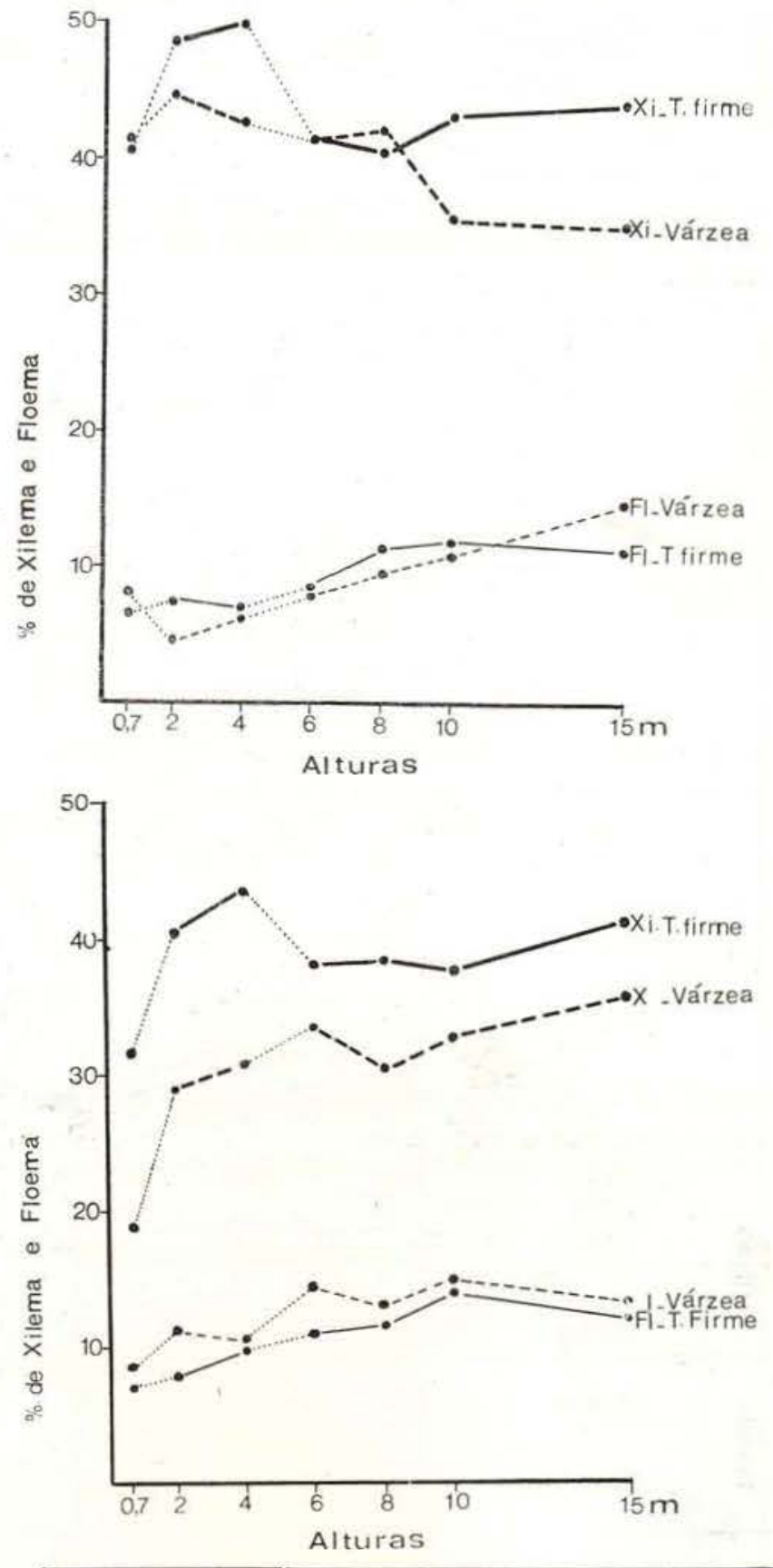

Fig. 23 - Percentagens médias de tecidos condutores de pecíolo (A) e nervura central (B) nas diferentes alturas em plantas de várzea e terra firme. $\mathrm{Xi}$ - xilema; $\mathrm{FI}$ - floema. 


\section{PARÊNQUTMAS}

As percentagens de parênquima medular e cortical são mais altas nas plantas de várzea do que nas de terra firme.

Nos dois habitats, a percentagem de parênquima medular, em pecíolo e nervura cen

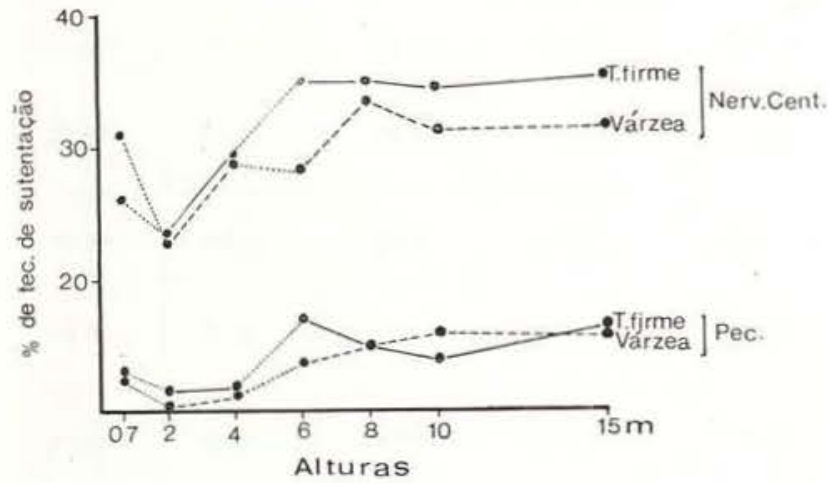

Fig. 24 - Percentagens correlativas de tecido de sustentação em pecíolo e nervura central nas diferentes alturas e nos dois habitats. tral, decresce com a altura da folha na planta, enquanto que a percentagem de parênquima cortical, incluindo epiderme, apresenta um ligeiro aumento (Tab. 31; Fig. 27).

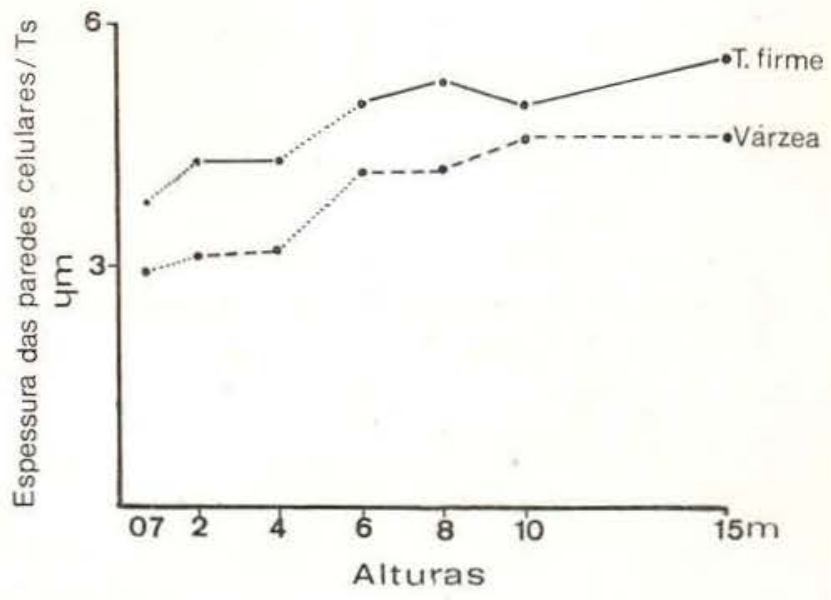

Fig. 25 - Espessura média da parede celular do tecido de sustentação nas diferentes alturas e nos dois habitats.
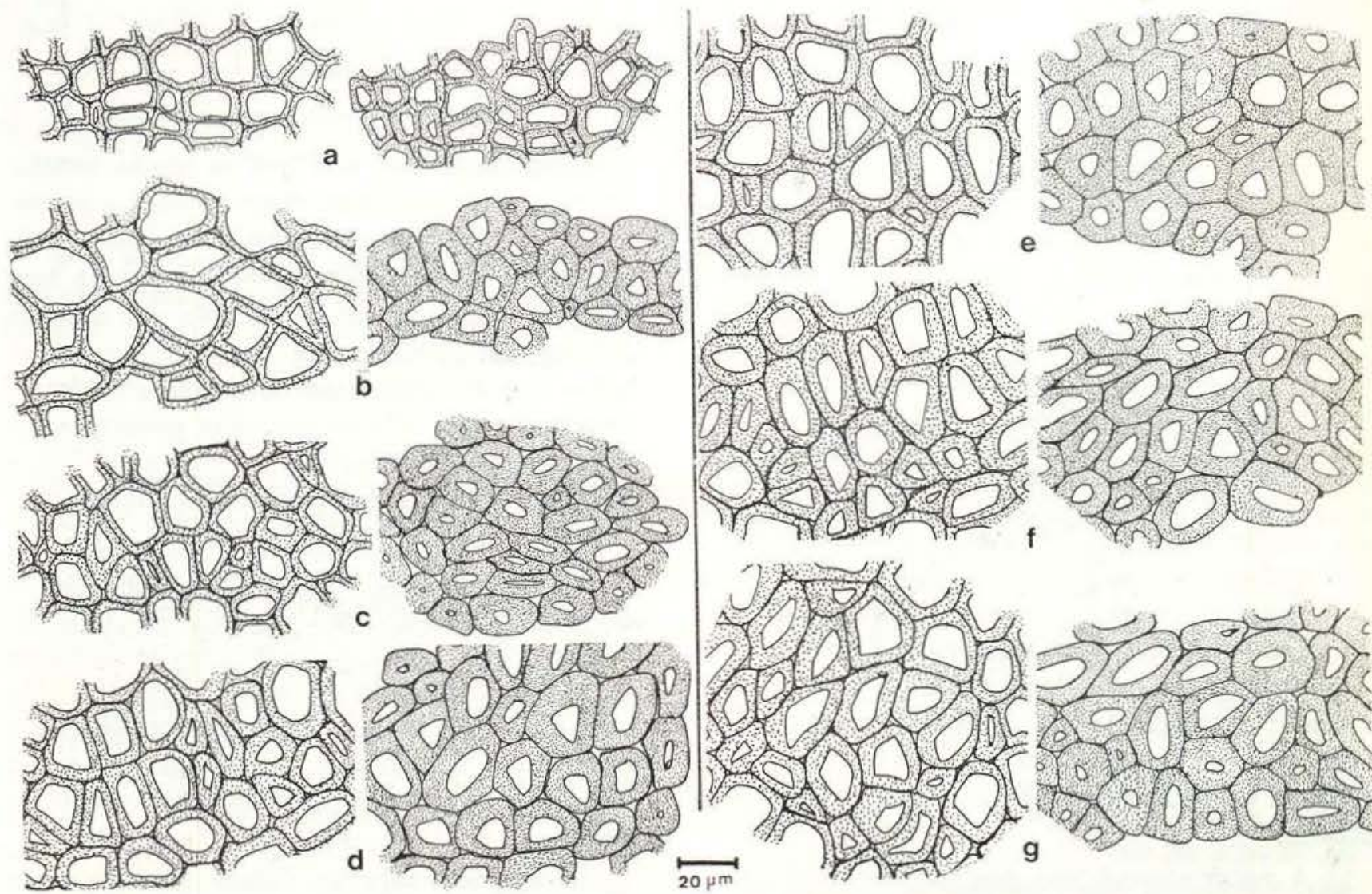

c
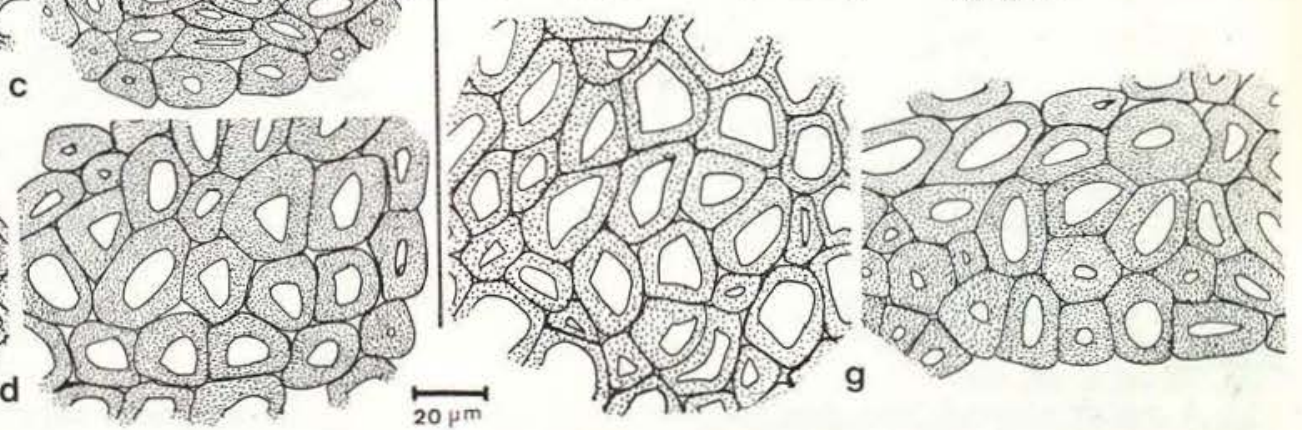

Fig. 26 - Comparaçāo de tecido de sustentação em plantas de várzea (esquerda) e terra firme (direita) nas diferentes alturas. A, 0,7 m (plântula); B, $2 \mathrm{~m} ; \mathrm{C}, 4 \mathrm{~m} ; \mathrm{D}, 6 \mathrm{~m} ; \mathrm{E}, 8 \mathrm{~m} ; \mathrm{F}, 10 \mathrm{~m} ; \mathrm{G}, 15 \mathrm{~m}$. 
TABELA 31 - Percentagens médias dos parênquimas medular e cortical (incluindo epiderme) em pecíolo e nervura central nas diferentes alturas em plantas de várzea e terra firme.

\begin{tabular}{|c|c|c|c|c|c|c|c|c|c|}
\hline \multirow{2}{*}{ 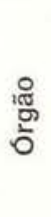 } & \multirow{2}{*}{$\begin{array}{l}\stackrel{ }{0} \\
\stackrel{0}{\circ} \\
\vdash\end{array}$} & Alt & \multicolumn{7}{|c|}{$\%$ de Parênquimas $(\bar{x})$} \\
\hline & & & $0.7 \mathrm{~m}$ & $2 \mathrm{~m}$ & $4 \mathrm{~m}$ & $6 \mathrm{~m}$ & $8 \mathrm{~m}$ & $10 \mathrm{~m}$ & $15 \mathrm{~m}$ \\
\hline \multirow{4}{*}{$\begin{array}{l}\frac{0}{0} \\
\frac{0}{0} \\
0\end{array}$} & $\frac{\pi}{3}$ & Várzea & 28,54 & 35,61 & 34,28 & 30,09 & 25,90 & 24,36 & 20,21 \\
\hline & $\bar{a}$ & Terra firme & 32,41 & 26,51 & 24,58 & 21,77 & 19,97 & 20,80 & 19,50 \\
\hline & త్ర్ & Várzea & 11,63 & 6,22 & 6,72 & 7,99 & 9,20 & 13,95 & 15,97 \\
\hline & $\ddot{0}$ & Terra firme & 7,45 & 6,58 & 6,98 & 9,90 & 13,52 & 10,23 & 9,00 \\
\hline \multirow{4}{*}{ 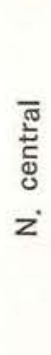 } & $\frac{\frac{1}{3 \pi}}{3}$ & Várzea & 28,97 & 22,47 & 17,17 & 12,13 & 7,14 & 5,92 & 5,74 \\
\hline & $\frac{E}{a}$ & Terra firme & 28,23 & 22,30 & 10,00 & 5,75 & 5,12 & 1,64 & 1,11 \\
\hline & ల్ర్ & Várzea & 12,72 & 13,24 & 13,20 & 11,61 & 15,57 & 15,00 & 13,77 \\
\hline & 0 & Terra firme & 6,23 & 6,00 & 8.88 & 10,00 & 10,44 & 12,79 & 10,40 \\
\hline
\end{tabular}

\section{DISCUSSÃO E CONCLUSÃO}

A redução gradativa no tamanho das células epidérmicas comuns, espessamento de parede e aumento em espessura da cutícula com a maior altura na planta poderia ser entendido. desde o ponto de vista ecológico, como uma estratégia contra a perda excessiva de água nos estratos mais xerofíticos. Sendo que o espessamento das paredes leva a uma redução de lúmem celular, é possível que estas células tenham menos água livre do que as células epidérmicas dos estratos inferiores com paredes finas e lúmem grande. A água absorvida está retida mais fortemente, e é mais dificilmente cedida do que a água livre. A cutícula mais grossa também pode atuar evitando a perda de água em folhas de ambientes xerofíticos.

A maior sinuosidade das células epidérmicas já foi anotada por Zalenski (citado em Maximov, 1931) e comentada por Lleras. Em Hevea brasiliensis, as sinuosidades reduzem pro- gressivamente com a altura na planta estabelecendo uma correlação negativa com a parede celular que se espessa. Nas folhas dos estratos inferiores, é menor a percentagem de tecido mecânico e menor a venação por unidade de área, sendo estas mais flexíveis do que as folhas dos estratos superiores. Uma epiderme constituída por células sinuosas poderia estar melhor adaptada a resistir tensões superficiais causadas pela maior flexibilidade (Lleras $\mathrm{s} / \mathrm{d}$ ).

$\mathrm{O}$ aumento do número de estômatos por unidade de área já foi discutido amplamente por Salisbury (1927) e Lleras (1977). Em condições mais xéricas, a folha precisa aproveitar o tempo limitado de umidade relativa alta mais eficiente para realizar trocas de gases com o meio ambiente, o que explica uma maior área de poros (área estomática útil, segundo Lleras).

A elevada relação volume-superfície em folhas sob condições xerofíticas já foi anotada, entre outros, por Shields (1950), Esau (1960) e Larcher (1975). Este caráter predomi- 

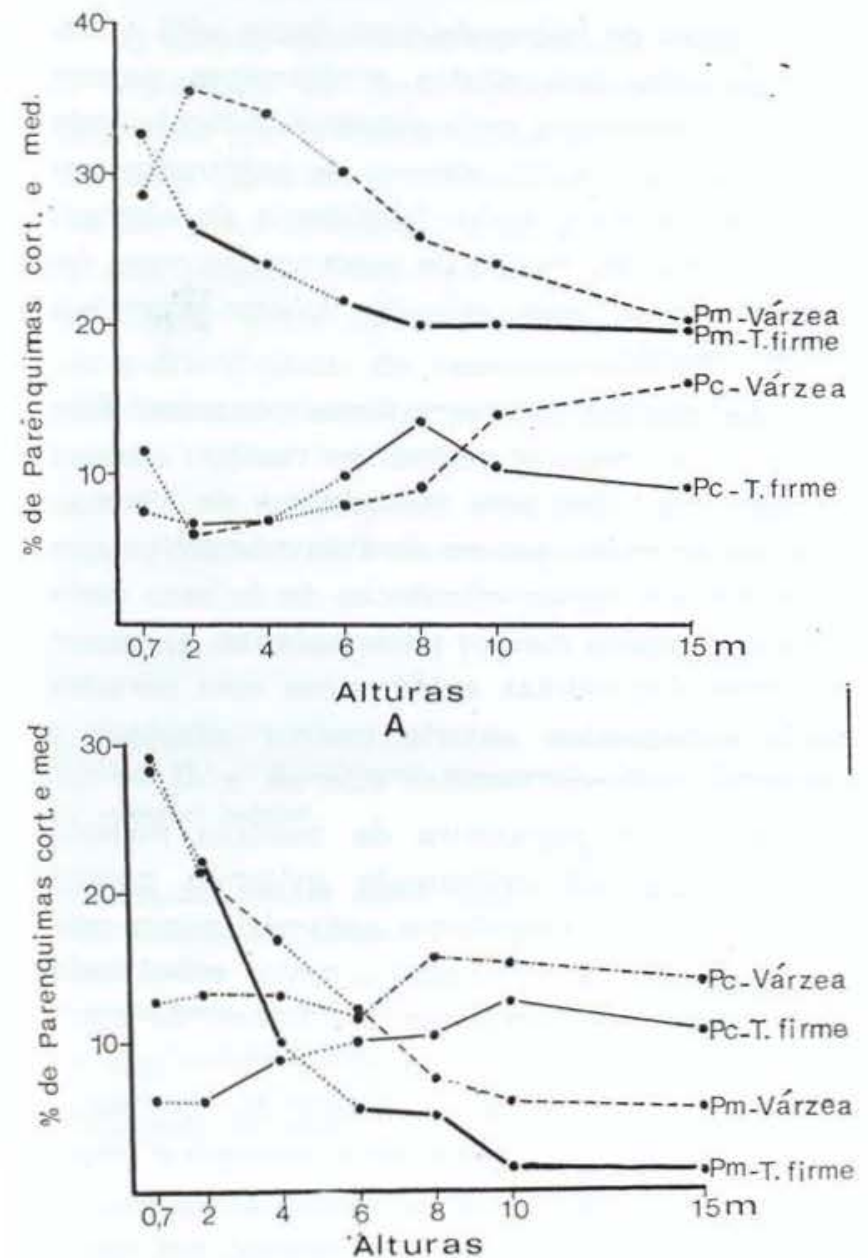

B

Fig. 27 - Percentagens médias de parênquimas medular e cortical em pecíolos (A) e nervura central (B) nas diferentes alturas em plantas de várzea e terra firme. $\mathrm{Pm}$, perênquima medular; Pc, parênquima cortical.

nantemente de folhas esclerófitas está associado ao espessamento do mesófilo, alongamento das células paliçádicas, redução dos espaços intercelulares, rede vascular compacta e reforço mecânico das folhas. Cowart (1935), Turrell (1936 e 1944), Pickett (1937) e Esau (1960) verificaram que as folhas de sol são mais espessas que as folhas de sombra. Wylie (1949) anotou que folhas desenvolvidas sob a ação direta da luz são menores porém mais espessas. O aumento progressivo da relação volume-superfície com a altura parece estar influenciado por uma maior concentração de auxinas no interior de folhas sob condições xerofíticas (Lleras, $s / d$ ). Do ponto de vista ecológico, a elevada relação volume-superfície é uma adaptação com função tampão. A influência dos fatores externos será menor quanto menor a área exposta e maior volume. Portanto, em ambientes xéricos, a redução da área de transpiração com relação ao volume é vantajosa ecologicamente.

Nas folhas situadas em condiçōes de alta luminosidade, a maior espessura do mesófilo (maior volume), funciona como um tampão para a filtração da luz além de aumentar a quantidade de parênquimas fotossintéticos, especialmente de parênquima paliçádico (Cowart, 1935; Anderson, 1955).

O menor tamanho das folhas sob condições xerofiticas já foi comentado entre outros por Zalenski (1904). Shields (1950), Anderson (1955) e Sinnott (1960). Larcher (1975) postulou que quanto menores e mais subdivididas as folhas e maior a velocidade do ar, maior será o intercâmbio de calor com o meio ambiente. Sendo que o calor tende a fluir pela superfície da lâmina e ser perdido pelas margens e o ápice, qualquer adaptaçăo que aumente o perímetro marginal e o(s) ápice(s) sem afetar a relaçăo área superficial-volume será bem mais afetiva na perda de calor (Lleras, $s / d$ ).

A maior venação por unidade de área em folhas sob condições xerofíticas foi anotada, entre outros, por Zalenski (citado em Maximov, 1931); Shields (1950), Stalfelt (1956), Esau (1960) e Larcher (1975) enquanto que, Hasman \& Inanç (1957) postularam um sistema vascular fracamente desenvolvido em folhas hidromorfas. A maior venação por unidade de área em folhas sob condições xerofíticas está positivamente correlacionado com o maior número de estômatos, sendo do ponto de vista ecológico, mais eficiente já que nas condições citadas a folha necessitaria aproveitar períodos mais curtos para a realização das trocas gasosas. Além do suprimento hídrico eficiente. através de maior quantidade de elementos condutores xilemáticos, estas folhas apresentam nervuras com tecido floemático mais desenvolvido, concomitante com a maior quantidade de tecidos fotossintéticos do mesófilo.

Lleras (s/d) explica a formação de maior quantidade de tecido vascular em base a uma maior concentração de auxinas no interior do mesófilo em condições mais iluminadas, baseado nos trabalhos de Wetmore \& Rier (1963) e Dalessandro \& Roberts (1971). A maior percentagem de floema pode ser explicada basea- 
dos na maior eficiência fotossintética das foIhas de sol (Larcher, 1975) o que vai produzir uma concentração alta de açúcares. Dalessandro \& Roberts (1971) determinaram que a proporção entre xilema e floema está determinada pela relação entre concentração de auxinas e concentração de açúcares. A maior concentração relativa de auxinas, mais elementos $\mathrm{xi-}$ lemáticos; a maior concentração de açúcares, maior percentagem de elementos floemáticos. (Estes aspectos já foram discutidos por Lleras, $s / d$ ).

O fato de reforços mecânicos serem mais desenvolvidos nas folhas sob condições xerofíticas foi postulado, entre outros, por Zalenski (1904, Apud Maximov, 1931) e Vasilevskaia (1954). Hasman \& Inanç (1957), trabalhando com folhas hidromorfas notaram que estas possuiam pequena quantidade de esclerênquima. Os reforços mecânicos destas folhas, representados por abundante desenvolvimento de esclerênquima, aumentam com a altura na planta (xerofitismo), e são interpretados como estruturas que reduzem os efeitos danosos produzidos pelo murchamento (Stalfelt, 1956; Lleras, $s / d$ ).

Pecíolos mais curtos e mais espessos, do ponto de vista mecânico, são melhor adaptados para prender a folha em níveis de maior ventilação, evitando possíveis torções e tensões. Sua maior espessura está diretamente ligada à maior quantidade de tecidos condutores e de tecidos mecânicos.

Shields (1950) e Vasilevskaia (1964) postularam que fatores ambientais podem induzir um grau de xeromorfia em folhas mesomorfas ou intensificar os caracteres xerófitos, enquanto que Stalfelt (1956) anotou que deficiências de nutrientes podem induzir aspecto xeromórfico mais forte do que a falta de umidade. Müller-Stoll (1947), Stalfelt (1956), Sinnott (1960), Esau (1960) e Lleras (s/d) anotam que baixa concentração de nutrientes o de induzir escleromorfismo.

As plantas de terra firme estando em so. lo com baixo teor de nutrientes minerais, possuem folhas mais esclerofíticas do que as das plantas de várzea, comparando alturas correspondentes. Dentre as características mais es- clerofíticas de folhas de terra firme está o menor tamanho das células epidérmicas, parede celular epidérmica mais espessa, cutícula mais desenvolvida, maior número de estômatos por unidade de área, maior freqüência de elementos condutores, tecido de sustentação mais desenvolvido e uma relação volume-superfície mais elevada.

As plantas de terra firme possuem dois problemas: água e nutrientes, ambos menos disponíveis que para as plantas de várzea. Quaisquer mudanças no sentido adaptativo que permitissem maior eficiência de folhas, seria ecologicamente melhor para a planta. O menor tamanho das células epidérmicas com paredes mais espessadas estaria melhor adaptado a suportar maiores tensões (Lleras, $s / d$ ).

A maior espessura da cutícula poderia atuar mais eficientemente evitando perder água. A maior freqüência estomática por unidade de área, assim como a maior quantidade de elementos xilemáticos em folhas de terra firme, pode ser entendido ao constatar que as plantas em solo com baixo teor de nutrientes têm que absorver, conduzir e transpirar mais para apanhar quantidades satisfatórias de nutrientes minerais, ainda não levando em conta períodos menores de água disponível no solo.

A maior relação volume-superfície dada pelo desenvolvimento do parênquima paliçádico e conseqüente redução das lacunas, em folhas de plantas de terra firme é uma adaptação eficiente como tampão, já que as tensões nas folhas tendem a ser mais freqüentes e mais fortes. O elevado desenvolvimento de tecidos de sustentação nestas folhas poderia ser interpretado como redutor dos efeitos danosos que poderiam ser produzidos pelo murchamento (Stalfelt, 1956).

Ao comparar os resultados obtidos neste trabalho com trabalhos anteriores dos mesmos autores, pode notar-se que Hevea brasiliensis apresenta plasticidade fenotípica grande ao ser comparada com outras espécies tais como Pogonophora schomburgkiana (Leite \& Lleras, 1978) e Bertholletia excelsa (Medri \& Lleras, $\mathrm{s} / \mathrm{d})$. Esta plasticidade fenotípica relativamente grande provavelmente indica também maior adaptabilidade a variações ambientais. 
O estudo das faixas de variação fenotípica de indivíduos de populações naturais ou clo. nais pode ser utilizado como critério de seleção para obterem-se clones com características de maior tolerância a seca. Até o presente, não existem trabalhos em Hevea fazendo a correlação entre as características morfológicas e anatômicas de resistência à seca com experimentos fisiológicos que comprovem de maneira definitiva estas tendências. Nossa equipe tem atualmente iniciado pesquisas a este respeito com 6 clones de interesse econômico e esperam-se resultados a respeito nos próximos 18 meses.

TABELA 32 - Xerofitismo progressivo em folíolos de um mesmo habitat.

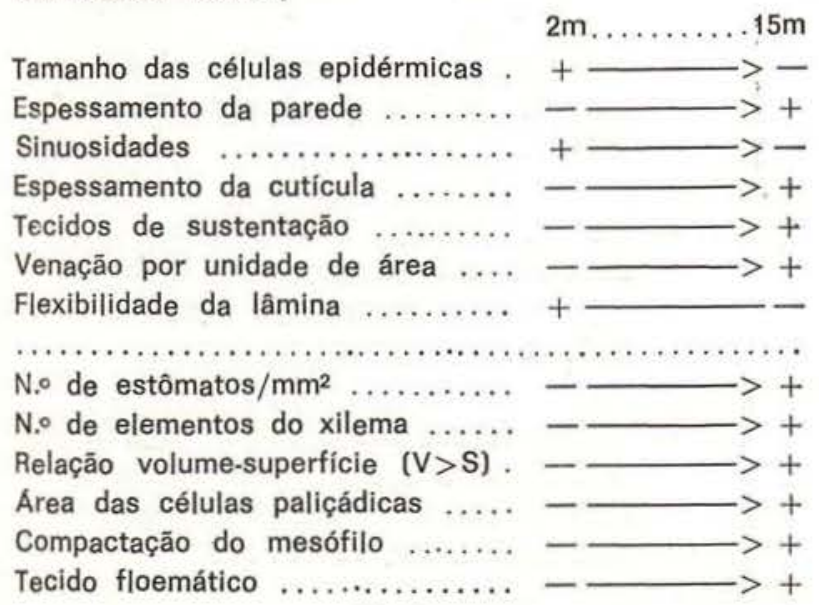

TABELA 33 - Xerofitismo habitacional e Esclerofitismo nutricional comparando plantas de terra firme com plantas de várzea.

Plantas Plantas de de várzea T. firme

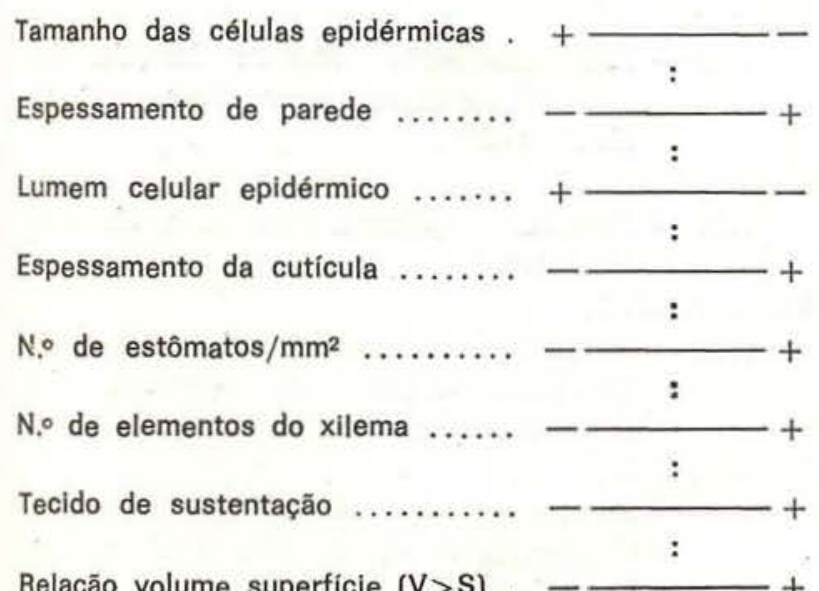

Em resumo, podemos concluir (Tabelas 32 e 33):

- que estes resultados estão de acordo com a lei de Zalenski, em que folhas sob condições xerofíticas apresentam células epidérmicas menores (com as limitações postuladas por Lleras), maior número de estômatos por unidade de área, paredes mais espessas e menos sinuosas nas células epidérmicas, diferenciação marcante entre os parênquimas paliçádico e lacunoso, menos espaços intercelulares, tecido mecânico desenvolvido e maior venação por unidade de área;

- diferenças entre folhas correspondentes (em altura) de plantas de várzea e terra firme, além de as condições mais xéricas nos estratos mais altos poderem postular uma açäo sinergética do menor teor de nutrientes, ficando superposto o efeito xérico e o efeito nutricional para dar folhas mais escleromorfas;

- as plântulas tanto de terra firme quanto de várzea apresentam características que estão fora da faixa de variação dadas as condições ambientais e nutricionais, sendo de fato elementos fisio-anatomicamente muito diferentes dos adultos.

\section{SUMMARY}

The comparative anatomy and morphology of the leaf of Hevea brasiliensis at diferent microclimates and habitats were studied. Leaves of diferent strata were compared, and comparisons were made with leaves of equivalent strata between plants growing in várzea and terra firme. The results show progressive xeromorphy with increase in height (as conditions become progressively more xeric) and more scleromorphy in leaves of comparable strata of terra firme than in várzea. The results thus agree with Zalenski's law and Lleras' interpretation of the same. The data here presented for Hevea brasiliensis suggest that this species shows more phenotypic plasticity than other species studied by the same authors. It is here suggested that based on comparisons of phenotypic plasticity within individuals of natural or clonal populations, it is possible, using the criteria here developed, to select genotypes that will show higher drought tolerance.

\section{BIBLIOGRAFIA}

ANDERSON, Y.G.

1955 - Seasonal development in sun and shade leaves. Ecology, $36: 430-439$. 
ARENS, $\mathrm{K}$.

1958a - Considerações sobre as causas de xeromorfismo foliar. Bol. Fac. Ciênc. Letr. Univ. São Paulo, 224 Bot. $15: 25-56$.

$1958 \mathrm{~b}$ - O cerrado como vegetação oligotrófıca. Bol. Fac. Fil. Ciênc. Letras Univ. São Paulo, 224 Bot. $15: 57-77$.

BOBILIOFF, W.

1973 - Anatomy and physiology of Hevea brasiliensis. Vol. 1 Art. Institut Orell Fossli, Zürich. $150 \mathrm{p}$.

BÜCHERL, W,

1962 - Introdução às técnicas microscópicas. 4 ed. São Paulo, Ed. Polígono, 178 p.

Brotherton, W. JR. \& Bartlett, H.H.

1918 - Cell measurement as an aid in the analysis of variation. Amer. Jour. Bot., 5 : 192-206.

Cailloux, M. \& lleras, E.

1979 - Fusão de Protoplastos de Hevea brasiliensis Müell. Arg. Estabelecimento da técnica. Acta Amazonica, 9(1): 9-13.

COWART, F.F.

1935 - Apple leaf structure as related to position of the leaf upon the shoot and to type of growth. Am. Soc. Hort. Sci. Proc., 33: 145-148.

Dalessandro, G. \& RoberTs, L.W.

1971 - Induction of xylogenesis in pith parenqchyma explants of Lactuca. Amer. Jour. Bot., $58: 378-385$

Esau, $\mathrm{K}$.

1960 - Anatomy of seed plants. New York, Wiley \& Sons. $376 \mathrm{p}$.

HaSman, M. \& INANÇ, N.

1957 - Investigations on the anatomical structure of certain submerged floating and amphibious hydrophytes. Istambul Univ. Rev. Facul. Sci. Ser. B. Sci. Nat., 22 : 137-153.

LARCHER, W

1975 - Physiological plant ecology. Berlin, Springer verlag. $252 \mathrm{p}$.

Leite, A.M. \& Lleras, E.

1978 - Ecofisiologia de plantas da Amazônia. I Anatomia foliar e ecofisiologia de Pogonophora schomburgkiana Miers. (Euphorbiaceae). Acta Amazonica, 8(3) : 365-370.

Lleras, E.

1977 - Differences in stomatal number per unit area within the same species under different micro-environmental conditions: A working hypothesis. Acta Amazonica, $7(4): 473-476$.

s/d - Aspectos básicos da morfologia e anatomia das folhas e sua relação com parâmetros fisiológicos. Anais do II Congresso Latino-Americano de Botânica (no prelo).
Lleras, E. \& MEdri, M.E.

1978 - Comparação anatômica entre folhas diplóides e poliplóides do híbrido Hevea brasiliensis $x$ benthamiana (IAN 717). Acta Amazonica, 8(4) : 565-575.

Medri, M.E. \& Lleras, E.

1979 - Ecofisiologia de Plantas da Amazônia. 2 Anatomia foliar e ecofisiologia de Bertholletia excelsa Humb. \& Bonpl. (Castanhado-pará) Lecythidacaea. Acta Amazonica, 9(1) : 15-23.

s.d. - Comparação anatômica entre folhas de um Clone Diplóide (IAN 873) e dois Clones Poliplóides (IAC 207, 222) de Hevea brasiliensis Müell. Arg. (entregue $\mathrm{p} /$ publicação).

MaXimov, N.A

1931 - The physiological significance of the xeromorphic structure of plants. Jour. Ecol.. $19: 273-282$.

MUller - STOLL, W.R.

1947 - Der Einfluss der Ernährung auf die xeromorphie der Hochmoopflanzen. Planta, 35 : 225-251

PICKetT, W.F.

1937 - The relationship between the internal structure and photosynthetic behavior of apple leaves. Kansas Agr. Expt. Sta. Tech. Bull., 42.

SAlisbury, E.J.

1927 - On the causes and ecological significance of stomatal frequency, with special reference to woodland flora. Phil. Trans. Roy. Soc. London. ser. B., $46: 1-65$.

Selleck, G.W. \& Shuppert, K.

1957 - Some aspects of microclimate in a Pine Forest and an Adjacent Prairie. Ecology, $38: 650-653$

SHIFLdS, L.M.

1950 - Leaf xeromorphy as related to physiological and structural influences. Bot. Rev., 16 : 399-447.

SiEgeL, S.

1956 - Non parametric statistic for the behavioral sciences. New York, 312 p. McGraw - Hill .

SinnotT, E.W.

1960 - Plant morphogenesis. New York, McGrawHill. $550 \mathrm{p}$

Stalfelt, M.G.

1956 - Morphologie und anatomie des Blattes als Transpirationsorgan. In: Handbuch der pflanzephysiologie, $3: 324-341$.

TURRELL, F.M.

1936 - The area of the internal exposed surface of dicotyledon leaves, Am. Jour. Botany, $23: 255-264$ 
1944 - Correlation between internal surface and transpiration rate in mesomorphic ànd xeromorphic leaves grown under artificial light, Bot. Gaz., $105:$ 413-425.

VASILEVSKaiA, V.K.

1954 - Formirovanie lista Zasukhoustoichivykh rastenii. (Formation of leaves of drought - resistante plants) Akad. Nauk Turkmen SSR. 183 pp. (apud Esau, K. - Anatomy of seed plants. New York, John Wiley \& Sons. 376 p., 1960).

WETMORE, R.H. \& RIER, J.P.

1963 - Experimental induction of vascular tissue in the callus of angiosperms. Amer. J. Bot., 50 : 418-430.
Wruie, R.B.

1949 - Differences in foliar organization among leaves from four locations in the crown of an isolated tree (Acer platanoides). lowa Acad. Sci. Proc., 56, 56 : 189-198.

YAPP, R.H

1912 - Spiraea Ulmaria and its bearing on the problem of xeromorphy in marsh plants. Ann. Bot., $26: 815-870$.

ZALENSKI, V

1904 - Materials for the study of the quantitative anatomy of different leaves on the same plant. Mem. Polytech. Kiv., 4:1-20 (Apud Maximov, N.A. The physiological significance of the xeromorphic structure of plants. Jour. Ecol., $19: 273-282,1931$ ).

(Aceito para publicação em 22/02/79) 